University of Wollongong

Research Online

Faculty of Engineering and Information

Faculty of Engineering and Information

Sciences - Papers: Part A

Sciences

$1-1-2016$

\title{
Analytical solution and numerical simulation of vacuum consolidation by vertical drains beneath circular embankments
}

Buddhima Indraratna

University of Wollongong, indra@uow.edu.au

Mojtaba E. Kan

University of Wollongong, mojtaba@uow.edu.au

David Potts

Imperial College London

Cholachat Rujikiatkamjorn

University of Wollongong, cholacha@uow.edu.au

Scott W. Sloan

University of Newcastle

Follow this and additional works at: https://ro.uow.edu.au/eispapers

Part of the Engineering Commons, and the Science and Technology Studies Commons

Research Online is the open access institutional repository for the University of Wollongong. For further information contact the UOW Library: research-pubs@uow.edu.au 


\title{
Analytical solution and numerical simulation of vacuum consolidation by vertical drains beneath circular embankments
}

\author{
Abstract \\ This paper presents an analytical solution and numerical simulation of vacuum consolidation beneath a \\ circular loading area (e.g. circular oil tanks or silos). The discrete system of vertical drains is substituted \\ by continuous concentric rings of equivalent drain walls. The effectiveness of the vacuum as distributed \\ along the drain length and the well resistance of the drains are considered. A rigorous solution of radial \\ drainage towards cylindrical drain walls is presented and compared to numerical FEM predictions. The \\ model is then successfully adopted to analyse the vacuum consolidation of a circular embankment in the \\ Ballina field testing facility in Australia.

\section{Disciplines} \\ Engineering | Science and Technology Studies

\section{Publication Details} \\ Indraratna, B., Kan, M. E., Potts, D., Rujikiatkamjorn, C. \& Sloan, S. W. (2016). Analytical solution and \\ numerical simulation of vacuum consolidation by vertical drains beneath circular embankments. \\ Computers and Geotechnics, 80 83-96.
}




\section{Analytical Solution and Numerical Simulation of Vacuum Consolidation by Vertical Drains beneath Circular Embankments}

\section{Buddhima Indraratna}

BSc (Hons., Lond.), MSc (Lond.), DIC, PhD (Alberta), FTSE, FIEAust., FASCE, FGS

Distinguished Professor of Civil Engineering, Faculty of Engineering, Director, Centre for Geomechanics and Railway Engineering; University of Wollongong, Wollongong City, NSW 2522, Australia

Mojtaba E. Kan

BSc (Hons), MSc, PhD (UNSW)

Research Associate, Centre for Geomechanics and Railway Engineering, School of Civil Engineering, Faculty of Engineering,

University of Wollongong, Wollongong City, NSW 2522, Australia

\section{David Potts}

BSc (Hons, Lond.), PhD (Cambridge), FRAE, FICE

GCG Professor of Geotechnical Engineering, Faculty of Engineering, Head of Geotechnics, Department of Civil and Environmental Engineering, Imperial College, London, UK

\section{Cholachat Rujikiatkamjorn}

BEng (Hons), MEng (AIT), PhD

Associate Professor, Centre for Geomechanics and Railway Engineering, School of Civil Engineering, Faculty of Engineering,

University of Wollongong, Wollongong City, NSW 2522, Australia

Scott W. Sloan

BE (Hons I, Monash), MEng, MPhil, PhD (Cambridge), FRS

Laureate Professor of Civil Engineering and Director of Australian Research Council Centre of Excellence for Geotechnical Science and Engineering,

The University of Newcastle, Callaghan, NSW 2308, Australia

Prepared for submission to: Computers and Geotechnics

No. of Words (without abstract and references): 5788, No of Figures: 16, No of Tables: 3 


\title{
Analytical Solution and Numerical Simulation of Vacuum Consolidation by Vertical Drains beneath Circular Embankments \\ Buddhima Indraratna, Mojtaba E. Kan, David Potts, Cholachat Rujikiatkamjorn, and Scott W. Sloan
}

\begin{abstract}
This paper presents an analytical solution and numerical simulation of vacuum consolidation beneath a circular loading area (e.g. circular oil tanks or silos). The discrete system of vertical drains is substituted by continuous concentric rings of equivalent drain walls. The effectiveness of the vacuum as distributed along the drain length and the well resistance of the drains are considered. A rigorous solution of radial drainage towards cylindrical drain walls is presented and compared to numerical FEM predictions. The model is then successfully adopted to analyse the vacuum consolidation of a circular embankment in the Ballina field testing facility in Australia.
\end{abstract}

Keywords: Analytical solution, Vertical drains, Consolidation, Vacuum preloading, Circular Embankments 


\section{Introduction}

Very soft clays are widespread in many coastal regions of Australia and other parts of the world. These soft clay deposits normally show unfavourable soil properties such as low bearing capacity and high compressibility. For such soils, appropriate ground improvement techniques are usually employed to minimize the post-construction settlements and lateral displacements which may threaten the stability of infrastructure built on them (Indraratna and Chu, 2005).

Application of prefabricated vertical drains (PVDs) is one of the most widely used ground improvement techniques for improving the mechanical properties of soft clay deposits. The PVDs expedite the progress of soil consolidation by shortening the length of the drainage path and enhancing radial drainage. PVDs are artificially created vertical drainage boundaries which accelerate lateral (radial) flow from the surrounding soil, thereby increasing the rate of consolidation significantly. The consolidation of the soil results in higher shear strength and helps to reduce the post-construction settlement of the super-structure (Holtz et al., 1991). However, preloading with PVDs can be relatively slow, as a staged construction is generally required to prevent instability. In such cases, the application of vacuum pressure would significantly reduce the consolidation time (e.g. Indraratna et al., 2005, Dam et al., 2006).

The behaviour of vertical drains was first solved analytically by Barron (1948) and Richart (1957) based on a unit cell concept. The unit cell represents a single drain surrounded by a soil annulus under axisymmetric conditions (three-dimensional, 3D). Hird et al. (1992) extended the unit cell concept to the plane strain condition (two-dimensional, 2D). The unit cell concept is accurate when applied at the embankment centreline, where the lateral displacements are negligible. In practice, the subsoil is usually not uniform, and the process of consolidation is not always a one-dimensional problem (Indraratna et al., 1992). Numerical modelling of multidrain systems in plane strain was further improved by Indraratna and 
Redana (2000), who introduced a mathematical technique to convert axisymmetric properties to equivalent $2 \mathrm{D}$ plane strain condition and also considered the smear effect caused by mandrel intrusion.

The vacuum preloading (VP) method was initially introduced in Sweden by Kjellman (1952) for cardboard wick drains. The 2D analysis is also applicable for VP in conjunction with vertical drains (e.g. Gabr and Szabo, 1997). Mohamedelhassan and Shang (2002) proposed an analytical solution for radial consolidation with vacuum application. Indraratna et al. (2005) extended the unit cell radial consolidation theory for vacuum application, based on the equivalent plane strain condition and considering the potential vacuum loss along the drain length. It can be noted that most of the previous studies have been devoted to modelling the multidrain systems corresponding to an embankment strip loading in 2D plane strain. So far, no study has been conducted to model vacuum consolidation via PVDs beneath a circular loaded area, where the system conforms to an axisymmetric problem. Ground improvement, however, may be needed for most heavy circular structures, such as oil or water storage tanks, silos, and heavily loaded roundabouts in commercial areas. Indraratna et al. (2008) first introduced the concept of concentric rings of equivalent drain walls for simulating circular embankments with PVDs, but this work was limited to conventional preloading with vertical drains and no vacuum pressure.

The main objective of this paper is to introduce a comprehensive analytical solution for vacuum preloading in conjunction with vertical drains beneath a circular foundation. The theory of ring walls is extended to accommodate vacuum preloading, considering the possible loss of vacuum with depth and the effect of well resistance on consolidation. The finite element model (FEM) in PLAXIS (Brinkgreve et al., 2015), incorporating the author's solution, is then validated for a single ring situation. The FEM code PLAXIS is then used to analyse the performance of a full-scale test embankment to be constructed near the Pacific 
Highway in Ballina, NSW, Australia. The effect of vacuum pressure termination on the consolidation response and post-construction settlements are also analysed and a novel approach to determine the optimum time for terminating the vacuum application is presented and examined for the design of the Ballina circular embankment.

\section{Mathematical Formulation}

Vertical drains are generally installed either in equilateral triangular or square patterns. It is noted that the square pattern can be more easily controlled in the field, although the triangular pattern may give more uniform settlement (Rixner et al., 1986). The vacuum consolidation of soil around a single vertical drain can be readily analysed as a unit cell (Indraratna et al., 2005). However, to analyse a multidrain system under an axisymmetric condition, the equivalent soil parameters that give the same time-settlement response in the field must be determined. Indraratna et al. (2008) proposed a transformation scheme for axisymmetric problems in which each drain is assumed as a part of the concentric cylindrical drain wall with an increasing perimeter with the radial distance from the centreline, as shown in Figure 1. In this section, the ring wall theory is extended to incorporate the concept of vacuum consolidation for the analysis of circular loading, such as silos or oil and water storage tanks.

\subsection{Assumptions}

The main assumptions made in developing the analytical solutions are summarized below:

- Equal strain assumption and small strain theory are valid. The flow in the soil mass is assumed to be laminar and Darcy's law is adopted.

- Only vertical strains are allowed, i.e. at the centreline of a relatively large loading area, volume change is due to settlement only, and lateral displacements are negligible. 
- The soil is fully saturated and homogeneous, and the permeability of the soil is assumed to be constant during consolidation.

- Well resistance is taken into account. It is assumed that well resistance is constant during consolidation.

- Each set of vertical drains located at the same radial distance from the line of axisymmetry is modelled as a continuous cylindrical drain wall of radius $r_{i}=i . S$, where $S$ is the spacing of the drains and $i$ is the number of that set, as shown in Figure 1(c)

- It is assumed that the cylindrical drain wall has a negligible thickness.

- Each cylinder is assumed to be impermeable with respect to the outer and inner boundaries, and has an internal horizontal (radial) flow.

- Smear effects around the drain walls are not incorporated directly in the equations. It is assumed that the smear effect due to drain installation can be taken into account in by calculating the reduced lateral permeability of the soil (Indraratna and Redana, 1997).

- The vacuum pressure distribution along the drain boundary is considered to vary linearly from $-p_{0}$ at the top of the drain to $-k_{1} p_{0}$ at the bottom of the drain. The vacuum pressure is assumed to be evenly distributed in the horizontal direction between the adjacent drains.

\subsection{Analytical Solution}

Considering the inner hollow cylindrical soil wall, the flow rate in the radial direction from the inner impermeable boundary to the hollow cylindrical drain wall is expressed by Darcy's law, i.e. in zone (1) of Figure 2(a): 


$$
\frac{\partial Q}{\partial t}=\frac{k_{h}}{\gamma_{w}} \frac{\partial u}{\partial r} A
$$

where $Q$ is the flow in the soil mass, $u$ is the excess pore pressure due to preloading, and $A$ is the cross-sectional area of the flow at distance $r$ and can be expressed as $(2 \pi r d z)$ where $d z$ is the height of an arbitrary thin layer of the soil as shown in Figure 2(b). $\gamma_{w}$ is the unit weight of water, $t$ is time and $k_{h}$ is the horizontal permeability coefficient of soil.

The rate of volume change in the vertical direction of the soil mass can be expressed by:

$$
\frac{\partial V}{\partial t}=\frac{\partial \varepsilon_{v}}{\partial t} \pi\left[\left(r_{i}-\frac{S}{2}\right)^{2}-r^{2}\right] d z
$$

where $V$ is the volume of the soil mass and $\varepsilon_{v}$ is the volumetric strain.

The rate of radial flow is assumed to be equal to the rate of volume change of the soil mass in the vertical direction, therefore, by rearranging equations (1) and (2), the gradient of excess pore pressure can be derived as:

$$
\frac{\partial u_{1}}{\partial r}=\frac{\gamma_{w}}{2 k_{h}} \frac{\partial \varepsilon_{v}}{\partial t} \frac{1}{r}\left[\left(r_{i}-\frac{S}{2}\right)^{2}-r^{2}\right]
$$

where the index 1 refers to zone 1 in Figure 2(a).

Similarly, the gradient of excess pore pressure in Zone (2) of Figure 2(a) is determined by:

$$
\frac{\partial u_{2}}{\partial r}=\frac{\gamma_{w}}{2 k_{h}} \frac{\partial \varepsilon_{v}}{\partial t} \frac{1}{r}\left[\left(r_{i}+\frac{S}{2}\right)^{2}-r^{2}\right]
$$


Considering a horizontal cross-sectional slice with thickness $d z$ in Figure 2(b), the change of flow in the $z$ direction of the drain from the entrance to the exit of the slice, $d Q_{z}$, is then expressed by:

$$
d Q_{z}=\frac{q_{w}}{\gamma_{w}} \frac{\partial^{2} u}{\partial z^{2}} d z d t
$$

where the flow term $q_{w}$ represents well resistance.

The total change in flow from the inner impermeable boundary to the exit face of the slice $\left(d Q_{1}\right)$ is given by:

$$
d Q_{1}=\frac{2 \pi r_{i} k_{h}}{\gamma_{w}} \frac{\partial u_{1}}{\partial r} d z d t
$$

Similarly, the total change in flow from the outer impermeable boundary to the exit face of the slice $\left(d Q_{2}\right)$ is equal to:

$$
d Q_{2}=\frac{2 \pi r_{i} k_{h}}{\gamma_{w}} \frac{\partial u_{2}}{\partial r} d z d t
$$

If the water is assumed to be incompressible, then the following equation should be satisfied:

$$
d Q_{z}+d Q_{1}+d Q_{2}=0
$$

where $d Q_{z}$ is the total change in flow in the vertical direction. At the drain boundary, it is assumed that a sudden drop in pore water pressure does not occur. Therefore, substituting equations (5), (6) and (7) in equation (8) yields:

$$
\left(\frac{\partial u_{1}}{\partial r}\right)_{r=r_{i}}+\left(\frac{\partial u_{2}}{\partial r}\right)_{r=r_{i}}+\frac{q_{w}}{2 \pi r_{i} k_{h}}\left(\frac{\partial^{2} u}{\partial z^{2}}\right)_{r=r_{i}}=0
$$


Equation (9) governs the dissipation of pore pressure in the horizontal direction, and can be solved and simplified to yield the average excess pore water pressure, $\bar{u}$, in a given cylinder. Details of the derivations are given in the Appendix, where it is shown that $\bar{u}$ can be expressed as:

$$
\bar{u}=\frac{\gamma_{w}}{k_{h}} \frac{\partial \varepsilon_{v}}{\partial t} \frac{1}{8} d_{e}^{2} \mu_{\text {ring }}-\frac{p_{o}}{2}\left(1+k_{1}\right)
$$

where

$$
\begin{aligned}
\mu_{\text {ring }}= & \frac{\alpha^{2}}{i}\left[-2 i^{3}-1.5 i+2(i-0.5)^{4} \ln \left(\frac{i}{i-0.5}\right)\right. \\
& \left.+2(i+0.5)^{4} \ln \left(\frac{i+0.5}{i}\right)+\frac{4 k_{h} \pi L^{2} i}{3 q_{w}}\right]
\end{aligned}
$$

and $S=\alpha d_{e}$, with $\alpha=0.887$ and 0.952 for drains installed in a square pattern and an equilateral triangular pattern, respectively. Here $d_{e}$ is the equivalent diameter of soil cylinder around a single drain.

If the well resistance is ignored, i.e. when $q_{w}$ is large enough, $\mu_{\text {ring }}$ becomes:

$$
\mu_{\text {ring }}=\frac{\alpha^{2}}{i}\left[-2 i^{3}-1.5 i+2(i-0.5)^{4} \ln \left(\frac{i}{i-0.5}\right)+2(i+0.5)^{4} \ln \left(\frac{i+0.5}{i}\right)\right]
$$

The value of $\mu_{\text {ring }}$ in equation (12) converges to $2 \alpha^{2} / 3$ for all values of $i>4$, as shown in Figure 3, and therefore equation (11) can be rewritten as:

$$
\mu_{\text {ring }}=\frac{2 \alpha^{2}}{3}\left(1+\frac{2 k_{h} \pi L^{2}}{q_{w}}\right)
$$

Note that for small number of ring walls $(i<4)$, equation (12) is still required to determine the value of $\mu_{\text {ring }}$ rather than the limiting value of $2 \alpha^{2} / 3$. 
Combining equation (10) with the well-known compressibility relationship $\partial \varepsilon_{v} / \partial t=-m_{v} \partial \bar{u} / \partial t$ gives:

$$
\bar{u}=-\frac{\gamma_{w}}{k_{h}} m_{v} \frac{\partial \bar{u}}{\partial t} \frac{1}{8} d_{e}^{2} \mu_{\text {ring }}-\frac{p_{o}}{2}\left(1+k_{1}\right)
$$

where $m_{v}$ is the coefficient of volume compressibility for one-dimensional compression. Rearranging equation (14) and then integrating by applying the boundary condition $\bar{u}=\sigma_{1}$ at $t=0$ gives:

$$
\frac{\bar{u}}{\sigma_{1}}=\left[1+\frac{\left(1+k_{1}\right) p_{0}}{2 \sigma_{1}}\right] \exp \left(-\frac{8 T_{\text {ring }}}{\mu_{\text {ring }}}\right)-\frac{\left(1+k_{1}\right) p_{o}}{2 \sigma_{1}}
$$

where $T_{\text {ring }}=\frac{c_{h, \text { ring }} t}{d_{e}^{2}}$ and $c_{h, \text { ring }}$ is the coefficient of consolidation in radial direction for the ring. The average degree of horizontal consolidation can be found from (Indraratna et al., 2005):

$$
U_{h}=\frac{1-\bar{u} / \sigma_{1}}{1-\bar{u}_{\infty} / \sigma_{1}}=\frac{\sigma_{1}-\bar{u}}{\sigma_{1}+\left(1+k_{1}\right) p_{o} / 2}
$$

where $\bar{u}_{\infty} / \sigma_{1}$ can be calculated by equation (15) when $t \rightarrow \infty$ and can be taken as $-\left(1+k_{1}\right) p_{o} / 2 \sigma_{1}$

\subsection{Equivalent Parameters for Multidrain Analysis under 2D Axisymmetric Condition}

Equivalent parameters can be determined either by geometric transformation or permeability transformation (or both) to minimize the disparity between the two methods, plain strain and axisymmetric (Indraratna and Redana, 2000). For circular loading, the proposed procedure 
for conversion can be based on the equivalent average excess pore pressure by maintaining the geometric equivalence. In this procedure, the size and relative distance of the drain wall from the centre of the embankment under 2D conditions are assumed to be the same as those for the 3D condition.

For a vertical drain with vacuum preloading under axisymmetric conditions, the average excess pore pressure in a unit cell can be given by (Indraratna et al., 2005):

$$
\bar{u}=\frac{\gamma_{w}}{k_{h}} \frac{\partial \varepsilon_{v}}{\partial t} \frac{1}{8} d_{e}^{2} \mu_{a x}-\frac{p_{o}}{2}\left(1+k_{1}\right)
$$

where

$$
\mu_{a x}=\left[\ln \left(\frac{n}{s}\right)+\frac{k_{h}}{k_{s}} \ln (s)-\frac{3}{4}+\frac{2 k_{h} \pi L^{2}}{q_{w}}\right]
$$

and $n=d_{e} / d_{w}, s=d_{s} / d_{w}$, and $d_{s}$ and $d_{w}$ are the diameter of the smear zone and vertical drain, respectively. $k_{s}$ is the coefficient of horizontal permeability in the smear zone.

At a given stress level and at each time step, the average excess pore pressure for both the unit cell and a unit of revolving prism of soil are made the same by equating equation (17) with equation (10). The equivalent permeability for the multidrain system under axisymmetric conditions can then be expressed by:

$$
\frac{k_{h, \text { ring }}}{k_{h}}=\frac{\frac{2 \alpha^{2}}{3}\left(1+\frac{2 k_{h} \pi L^{2}}{q_{w}}\right)}{\left[\ln \left(\frac{n}{s}\right)+\frac{k_{h}}{k_{s}} \ln (s)-\frac{3}{4}+\frac{2 k_{h} \pi L^{2}}{q_{w}}\right]}
$$

where the equivalent vacuum pressure for both the two and three dimensional axisymmetric conditions are assumed to be the same. 


\section{Model Verification Using FEM}

The finite-element program PLAXIS (Brinkgreve et al., 2015), based on Biot's consolidation theory, was used to validate the proposed analytical solution. Indraratna et al. (2005) have reported the results of analytical and numerical modelling of unit cells of soft estuarine Sydney clay with and without vacuum for the corresponding material parameters. Using the same soil in the current study, a single ring drain of soft clay is simulated under axisymmetric conditions. Two cases are considered, Case A: a $10 \mathrm{~m}$ deep ring with constant vacuum pressure with depth (i.e. $k_{1}=1.0$ ), and Case B: a $50 \mathrm{~m}$ deep ring with decreasing vacuum pressure to be halved at $50 \mathrm{~m}$ depth (i.e. $k_{1}=0.5$ ). In both cases, the width of the ring is $1.2 \mathrm{~m}$ and the distance between the drain and axis of symmetry is assumed to be $6 \mathrm{~m}$, i.e. $r_{i}=6 \mathrm{~m}$ or $i=6 / 1.2=5$. The drain is $50 \mathrm{~mm}$ in diameter and surrounded by a smear zone of $170 \mathrm{~mm}$ in diameter. A total of 1840 and 8666 axisymmetric triangular elements (six-node quadratic displacement and linear pore pressure) were used in the finite element discretization to simulate the $10 \mathrm{~m}$ and $50 \mathrm{~m}$ deep rings, respectively (see Figure 4(a)). Each PVD is simulated using a linear drain element which acts as an internal free drainage boundary. The top, bottom, and outer boundaries were set as impermeable, and therefore drainage was limited to the horizontal direction towards the PVD. The relevant boundary conditions are shown on Figure 4(b). After establishing the in-situ stresses in the model with $K_{0}=1$, first the installation of PVD was simulated by activation of the drain element in the model and then a surcharge load of $\sigma_{1}=50 \mathrm{kPa}$ was applied on top of the ring. To capture the equal-strain condition, rigid elements were used at the top of the soil surface where only vertical displacement was only allowed to prevent any rotation. Application of surcharge was followed by a vacuum pressure of $p_{0}=-50 \mathrm{kPa}$ applied along the drain length. For the 
current FEM simulations conducted using PLAXIS, the fully implicit time-marching scheme with a default error tolerance of $1 \%$ was adopted to ensure adequate and swift convergence.

The soil behaviour is assumed to be linear elastic with $m_{v}=0.001 \mathrm{~m}^{2} / \mathrm{kN}$, and the case of zero lateral displacement was imposed (Poisson's ratio $=0$ ) for the unit cell. The values of $c_{h}$ $=0.32 \mathrm{~m}^{2} /$ year and $d_{e}=1.354 \mathrm{~m}$ (equivalent to $\mathrm{S}=1.2 \mathrm{~m}$ for square drain pattern) were used. The horizontal undisturbed soil permeability $\left(k_{h}\right)$ was taken as $10^{-10} \mathrm{~m} / \mathrm{s}$, and the ratio of the undisturbed permeability to the smear zone permeability $k_{h} / k_{s}$ was assumed to be 3.0 (Indraratna and Redana, 2000).

Figure 5 shows a comparison between the analytical and numerical models for Cases A and B. The normalized dissipation rate of excess pore water pressure with elapsed time is presented in Figure 5. The analytical solution presented is based on the calculations using equation (15), employing relevant material parameters for the clay. The ratio of pore water pressure dissipation in the numerical simulations is calculated in two different ways: first, using the average values of pore pressure at key points of the model (dashed line); second, using the ratio of the current settlement $\left(S_{t}\right)$ to the total settlement $\left(S_{f}\right)$, shown with a continuous line:

$$
\frac{S_{t}}{S_{f}}=\frac{\sigma_{1}-\bar{u}}{\sigma_{1}-\bar{u}_{\infty}} \Rightarrow \frac{\bar{u}}{\sigma_{1}}=1-\frac{S_{t}}{S_{f}}\left(1-\frac{\bar{u}_{\infty}}{\sigma_{1}}\right)
$$

where:

$$
\frac{\bar{u}_{\infty}}{\sigma_{1}}=-\frac{p_{0}\left(1+k_{1}\right)}{2 \sigma_{1}}
$$

and $\bar{u}_{\infty}$ represents the ultimate average pore water pressure. It can be seen in Figure 5 that the results of the numerical simulations are very close to the analytical solutions. The simulated 
curve for excess pore pressure based on the settlement is closer to the analytical results for $t<350$ and $t<500$ days, for cases A and B respectively. As the elapsed time exceeds these thresholds, the curves based on average excess pore pressure show better agreement with those predicted by the analytical solution. Small deviations are noted for the range 15-300 days with a maximum error of less than $3 \%$ in the degree of consolidation. The above matching procedure therefore confirms the reliability of the proposed procedure after transforming the true field condition to the equivalent axisymmetric drain rings.

\section{Application to a circular embankment currently being constructed along Pacific Highway in Ballina}

Design, construction and monitoring of the performance of a vacuum preloading circular embankment at the National geotechnical Field Testing Facility (BFTF) in Ballina NSW are now considered. The conversion method developed in this paper was used to perform numerical simulations of this VP circular embankment in the preliminary design stage. The VP circular embankment is being constructed and has a total height of $3.5 \mathrm{~m}$ and a crest diameter of $20 \mathrm{~m}$, with side slopes of $1.5 \mathrm{H}: 1 \mathrm{~V}$. The plan and typical cross section of the embankment are shown in Figure 6. The loading response of the VP circular embankment is simulated by a 2D equivalent axisymmetric model in PLAXIS (Brinkgreve et al., 2015) using the theory in the current study.

\subsection{Material parameters}

The material parameters are selected based on reported properties for the soil layers in the literature, mainly using the parameters reported in Indraratna et al. (2012) for the Ballina Bypass project which was located approximately $1 \mathrm{~km}$ away from the intended location for construction of the VP circular embankment. Results of a series of more recent site 
investigations at the Ballina Site, as reported in Li et al. (2014), Kelly et al., 2014 (2014), and Pineda et al. (2014, 2016), are also taken into account in current study.

Based on the published data regarding soil layers in the Ballina area, the required material parameters in the present study are listed in Table 1. The material parameters for the crust, sand/clay transition and fine sand layers are based on a Mohr-Coulomb model, while for the soft clay layer the 'Soft Soil' model of PLAXIS is selected for simulations. The permeability of the soil layers in the horizontal direction $\left(k_{h}\right)$, and the equivalent ring drain $\left(k_{h, r i n g}\right)$, are listed in Table 1 and will be discussed further in the following sections. The embankment fill is assumed as Mohr-Coulomb material with the properties given in Table 2.

\subsection{Mesh discretization and model set up}

The proposed VP circular embankment at the Ballina Site was simulated in PLAXIS, using a 2D axisymmetric model and the associated conversion procedure (Eq. 19). The vertical drains are installed in a square pattern. The model is extended laterally for $50 \mathrm{~m}$ in order to minimize the effects of the lateral boundaries, as shown in Figure 7. The smear effect of the PVD installation is taken into account indirectly by reducing the horizontal permeability $\left(k_{h}\right)$ of the soil in the surrounding area. The corresponding mesh, boundary conditions and selected control points of the VP circular embankment are shown on Figure 7. A total number of 4535 triangular 6-node elements are used for the discretization. The bottom and side boundaries were set as impermeable to simulate the axisymmetric condition. The water table is assumed to be at the ground surface and the initial stress state in the ground is simulated using the $K_{0}$ values listed in Table 1. PVDs are simulated using drain elements with the vacuum feature. The vacuum feature in PLAXIS is based on reduction of the pore-water pressure head to simulate the applied vacuum. 
The fully implicit time marching scheme of PLAXIS was used in the simulations (Brinkgreve et al., 2015). Preliminary analyses show that large deformations may occur in soft soil layers, therefore the influence of the mesh geometry change on the equilibrium conditions is considered in the FEM simulations capturing the finite strain approach. The finite strain computation procedure in PLAXIS is based on a Lagrangian formulation (Bathe, 1982) which updates the finite element mesh and the stiffness matrix at the beginning of each load step as the iteration proceeds.

\subsection{Smear characteristics and conversion of the permeability}

The extent of the smear zone created by drain installation can be obtained by assessing the variation of compressibility, permeability and water content of the soil samples obtained along the radius from the PVDs (Indraratna and Redana, 1998, Indraratna et al., 2014). In the present work, the size of the smear zone is calculated based on the available information in the literature. The diameter of the drains $\left(d_{w}\right)$ is $34 \mathrm{~mm}$, and the size of the rectangular mandrel is $125 \times 60 \mathrm{~mm}$ with an equivalent diameter $\left(d_{m}\right)$ of $92.5 \mathrm{~mm}$. Indraratna et al. (2012) have used a smear size ratio of $s=d_{s} / d_{w}=3$ for the past Ballina Bypass trial embankment. Parsa-Pajouh et al. (2014) showed that the ratio of $s=4$ gives the best match between the numerical model and field observations of the Ballina Bypass trial embankment. In multi-layer soils in the field, the smear effects might be due to combination of both mandrel action and the down-dragged soils from the upper layers (Casagrande and Poulos, 1969). Indraratna et al. (2014) performed field sampling and laboratory investigations to characterise the smear zone during installation of band shaped vertical drains at the Ballina Site. Based on the variations in the permeability, they found that the smear zone could be at least 6 times greater than the equivalent dimension of the mandrel, while the horizontal permeability 
within the smear zone varied from 0.2 to 0.9 of the lateral permeability of the undisturbed soil.

Based on past background, the diameter of the smear zone was taken as $200 \mathrm{~mm}$ in the current study, which resulted in a smear size ratio of $s=5.9$. The horizontal permeability in the smear zone was assumed one third of the horizontal permeability in the undisturbed zone.

To calculate the horizontal permeability of the equivalent drain rings in the $2 \mathrm{D}$ axisymmetric model, the conversion procedure described earlier in this paper has been used. Considering the short length of the drains, the effect of well resistance can be ignored so that equation (19) simplifies to:

$$
\frac{k_{h, \text { ring }}}{k_{h}}=\frac{\frac{2 \alpha^{2}}{3}}{\ln \left(\frac{n}{s}\right)+\frac{k_{h}}{k_{s}} \ln (s)-0.75}
$$

where $n=d_{e} / d_{w}=(1.2 \times 1.128) / 0.034=39.8, s=d_{s} / d_{w}=5.9$, and $\alpha=1 / 1.128=0.887$.

Assuming $k_{h} / k_{s}=3$, the permeability of the ring drain can be calculated. The conversion equation (Eq. 22) is used to calculate the corresponding values of the permeability of the equivalent rings in Table 1. This simplification significantly reduces the number of elements for the domain discretization, and accelerates the speed of convergence extensively.

\subsection{Loading history}

The proposed time history of fill construction and application of vacuum was considered, and this comprised of constructing a $0.6 \mathrm{~m}$ thick working platform (sand) in 5 days, installation of PVDs and monitoring instruments in 20 days, placing a $0.6 \mathrm{~m}$ thick sand blanket and the final layer of random fill with total height of $2.3 \mathrm{~m}$ in 25 days, and then the application of a $70 \mathrm{kPa}$ vacuum. The idealized time history of embankment construction and vacuum loading adopted 
in the FEM simulations is shown in Figure 8(a). Based on the unit weights of the fill materials given in Table 2, the total preloading due to both fill and the vacuum will be around $130 \mathrm{kPa}$, i.e. equivalent to a $7.5 \mathrm{~m}$ high embankment. Construction of such a high embankment on this soft soil would require staged construction and could be very timeconsuming as shown in Figure 8(b). Based on the material parameters adopted in Table 1, the mobilized shear strength will range from 1.5 to $3 \mathrm{kPa}$ at the top to the bottom of the soft clay and rapid construction of a high embankment on this ground condition will cause slide failure. The time history for construction of the $7.5 \mathrm{~m}$ high embankment in Figure $8(\mathrm{~b})$ is therefore based on a required elapsed time between each fill placement stage to gain enough strength in the underlying soil strata. By applying a vacuum head however, the duration of pre-consolidation could be reduced. The effect of vacuum application on the required time to achieve a certain level of consolidation will be further discussed in the following sections.

\subsection{Results and discussions}

Two possible field conditions are considered herein: application of vacuum after construction of a $3.5 \mathrm{~m}$ high embankment following the loading history shown in Figure $8(\mathrm{a})$, and the construction of a $7.5 \mathrm{~m}$ high embankment (no vacuum) to provide the same equivalent total pressure following the loading history shown in Figure $8(b)$ - introduced as 'Vacuum+Fill' and 'Fill Only', respectively. In order to avoid any boundary effects and to keep the geometry similar for both conditions, the $7.5 \mathrm{~m}$ high embankment is simulated by applying a corresponding uniform load on the crest of the $3.5 \mathrm{~m}$ high embankment, as shown in Figure

7. The staged construction of $7.5 \mathrm{~m}$ high embankment is simulated in such a way that, at each stage, the application of the new load increment (surcharge) will take place after $60 \%$ dissipation of the excess pore pressure at the middle of the soft clay layer. This is to ensure that the soft clay has gained adequate shear strength to bear the associated load without failure or significant increase in settlement. 
The settlement patterns of the ground surface after one year of consolidation with and without vacuum are shown in Figure 9. It can be seen that the total maximum settlement after one year of vacuum application is $1.99 \mathrm{~m}$, i.e. approximately twice that of the maximum deformation without vacuum during the same period of time under the surcharge loading of the $3.5 \mathrm{~m}$ high embankment.

The time history of the ground settlement at point A, located at the centreline of the embankment, is shown in Figure 10(a). It can be seen that for 'Vacuum+Fill' condition, the total settlement is around $1.8 \mathrm{~m}$ after 280 days, while for the 'Fill Only' condition this settlement takes almost one year longer. From the 'Vacuum+Fill' curve it is obvious that the rate of settlement decreases after almost three months of vacuum application. The same observation can be seen from the time histories of excess pore pressure at the middle of the soft clay (point C) as shown in Figure 10(b). As expected, the final excess pore pressure at point $\mathrm{C}$ for the 'Fill Only' condition approaches zero, and for the 'Vacuum+Fill' condition it eventually reaches $-70 \mathrm{kPa}$.

The contours of the horizontal displacements after one-year of vacuum application are shown in Figure 11. This shows that the horizontal displacements at the toe of the embankment are inward due to the effect of isotropic vacuum compression. This is further highlighted in Figure 12, where the profiles of the horizontal displacements at the toe of the embankment at various vacuum periods (up to 12 months) are compared with the corresponding profiles for the 'Fill Only' condition. Figure 12 shows that if a $7.5 \mathrm{~m}$ high embankment is constructed without any vacuum pressure, then the entire horizontal displacement is outward with a maximum displacement close to $0.21 \mathrm{~m}$. Application of the vacuum decreases the outward displacements and causes inward displacements in the soft clay (e.g. Chai et al., 2006, Chai and Carter, 2011). The maximum horizontal displacement after one year is $126 \mathrm{~mm}$ which occurs at a depth of $3.2 \mathrm{~m}$ below the surface. Only 3 months of vacuum application will be 
sufficient to neutralize the outward displacement along much of the soil profile, and this will control the maximum outward displacement to around $41 \mathrm{~mm}$. The time-dependent horizontal displacements for five selected key points located beneath the embankment toe are shown in Figure 13. Point D, located at the interface of surface crust and upper soft clay, shows outward horizontal displacement during the first 3 months of vacuum application and inward displacement afterwards. All other four points mostly show inward horizontal displacements during the period of vacuum application. Point E (located at a depth of $4 \mathrm{~m}$ ) always has the maximum inward displacements among the other points.

\subsection{Optimum time for the termination of vacuum}

The advantage of applying vacuum pressure diminishes with time as the primary consolidation progresses. As can be seen in Figure 10, the vacuum pressure accelerates the consolidation settlement significantly at the start, but subsequently shows marginal returns after about 120 days.

The cost savings for switching off of the vacuum pump early can be significant. This was demonstrated through a field trial at the Port of Brisbane reclamation site (Indraratna et al., 2011). Kianfar et al. (2015) performed a series of Rowe cell tests to study the suitable time for terminating the vacuum, and it was found that the amount of undissipated pore water pressure and its current rate of dissipation give a good indication of the best time to switch off the vacuum pumps. Kianfar et al. (2015) concluded that if the excess pore pressure is negative before vacuum removal, then the excess pore water pressures attain a relatively steady condition with no further settlement thereafter due to an existing fill. In the present study, first the unit cell analysis mimicking the laboratory testing by Kianfar et al. (2015) was conducted. It is confirmed that the numerical predictions can simulate the removal of vacuum application with acceptable accuracy compared with the laboratory observations. 
To study the effect of vacuum removal on the performance of vacuum consolidation in prototype scale, three cases were considered:

- Case A: Vacuum removal after 1 month

- Case B: Vacuum removal after 3 months

- Case C: Vacuum removal after 12 months

In each case, the vacuum was switched off after a certain time and the remaining consolidation was assumed to take place under the effect of surcharge pressure only. Results of the FEM simulations for these three cases are shown in Figure 14.

Figure 14(a) shows the time history of excess pore pressure at the middle of the soft clay (Point C) while the settlement curve at Point A is given in Figure 14 (b). In Case A, the vacuum removal takes place when the excess pore water pressure at Point $\mathrm{C}$ is still positive, i.e. the vacuum pressure does not have adequate time to lower the total pore pressure below the hydrostatic pore pressure at the same depth. So after vacuum removal, the pore water pressure first decreases swiftly due to the redistribution of pressure and then approaches the zero condition after almost 30 days. Meanwhile an extra settlement of $210 \mathrm{~mm}$ takes place. In Case $\mathrm{B}$, the excess pore water pressure upon vacuum removal is negative. The redistribution of stress after vacuum termination causes a much smaller change in the excess pore water pressure and just $30 \mathrm{~mm}$ of extra settlement occurs during a period of 650 days. In Case C, the vacuum is applied for 12 months, and the extra settlement after vacuum termination is negligible while the excess pore water pressure after vacuum termination reach zero within 150 days. In summary, this exercise clearly shows that for the Ballina circular embankment, the vacuum pumps can be stopped after 3 months and the subsequent limited settlement can occur under surcharge pressure. 
The effectiveness of vacuum application is further investigated considering the pre-consolidation pressure increments. Figure 15 shows the increments of pre-consolidation pressure $\left(\Delta p_{c}^{\prime}\right)$ with respect to the initial conditions, along a profile passing through the centerline of the embankment. As expected, as the duration of vacuum application increases, a higher pre-consolidation pressure is observed. However, the rate of increase in the preconsolidation pressure in the soft clay layer is not constant. While an average increment of around $25 \mathrm{kPa}$ can be observed during the first 3 months $(8.3 \mathrm{kPa}$ per month), the increment during the next 9 months is similar, at around $25 \mathrm{kPa}(2.8 \mathrm{kPa}$ per month), and about $15 \mathrm{kPa}$ during the next 12 months $(1.3 \mathrm{kPa}$ per month). The diminishing rate of increment in the pre-consolidation pressure implies that the effectiveness of the vacuum is reduced significantly after almost 3 months.

It should be noted that in terms of analytical solutions for vacuum termination, there are only limited documented solutions in the literature, attributed to inspiring works of Pariseau (1999), Belotserkovets and Prevost (2011) and Selvadurai and Suvorov (2012, 2014), which may be considered to extend the Biot type models to reflect the role of unloading due to vacuum termination.

\subsection{Effect of smear characteristics on vacuum termination}

The size of smear zone for the circular VP embankment was assumed to be $200 \mathrm{~mm}$ in diameter around each drain, and the smeared horizontal permeability was taken as one-third of the undisturbed soil. A sensitivity analysis is performed to investigate the range of expected outcomes for a variety of smear characteristics.

Parsa-Pajouh et al. (2014) showed that, based on past studies, the extent of the smear zone may vary from 1.6 to 7 times the equivalent drain size and the range of the undisturbed to smeared permeability ratios $\left(k_{h} / k_{s}\right)$ might be $1.3-10$. Very high values of $k_{h} / k_{s}$ are mainly 
reported for band shaped drains (e.g. Bergado et al., 1993) and for circular drains lower values are reported in the literature (e.g. Hansbo, 1997, Indraratna and Redana, 1998).

In the current study, a sensitivity analysis is performed for ratios of $d_{s} / d_{w}$ in the range of 2 to 6 , and $k_{h} / k_{s}$ varied from 1.5 to 5 . In each analysis, the smear zone characteristics are altered accordingly to observe the performance of vacuum pressure application. Results of this sensitivity analysis in terms of the time history of excess pore water pressure at the middle of the soft clay layer are shown in Figure 16. The required time to achieve the zero excess pore water pressure condition is indicated by the bullet points in Figure 16, and the corresponding values are summarized in Table 3. It is clearly evident that as the permeability of the smear zone increases or the size of the smear zone decreases, the desirable time for terminating the vacuum pressure decreases. For instance, the range of required time to switch off the vacuum pressure varies from a period of 38 days for $k_{h} / k_{s}=1.5$ and $d_{s} / d_{w}=2$ to 121 days for $k_{h} / k_{s}=5$ and $d_{s} / d_{w}=6$. This broad range was deliberately selected to examine the worst possible and the optimum scenarios when adopting the smear zone parameters in preliminary design. However, this aspect requires further insightful investigation that has not been covered within the scope of this study, but will be elaborated in the future, when the relevant field data become available for the vacuum stabilized circular embankment.

\section{Conclusions}

Construction of circular loaded structures such as oil tanks, silos, heavily built-on roundabouts, and circular embankments on soft soils requires effective consolidation to achieve higher shear strengths to minimize the post construction settlements. This paper presented a new technique to model vacuum consolidation via vertical drains beneath a circular loaded area, where the pattern of vertical drains could be transformed to a series of 
equivalent concentric (cylindrical) drain walls, and an analytical model for radial drainage was formulated. The proposed analytical formulation was validated using FEM simulations in the finite element code PLAXIS.

Application of the proposed model in practice was further examined by FEM simulation of a multidrain full-scale circular embankment at the Ballina Site, NSW, Australia. The settlements, excess pore-water pressures, and lateral movements in the embankment were analysed by employing the proposed conversion procedure. The termination time of the vacuum was also studied using the FEM simulations to provide insights into the optimum duration for application of the vacuum. It was concluded that the criteria of achieving zero or small negative excess pore water pressure prior to vacuum terminations works well for the Ballina circular embankment. Using these criteria, it was shown that the vacuum termination can occur in a 3 months period and the corresponding post-vacuum settlements are negligible under the existing fill. The vacuum termination was further studied by tracking the rate of increase in the pre-consolidation pressure along the centreline profile of embankment and it was shown that after the first 3 months, this significantly reduces and therefore the effectiveness of vacuum application would be insignificant. Sensitivity analyses were also performed to show the effect of smear characteristics on the optimum time of the vacuum switch off. Application of the suggested method for vacuum termination in practice requires selection of an appropriate representative point within the clay layer, and this selection requires further investigation.

The analytical solutions, validated by FEM modelling, provide a sound basis for the design of heavy circular foundations on soft clay. Moreover, the validation of the Authors' theoretical formulations for the proposed circular embankment near the Pacific Highway in Ballina with field measurements, is expected to begin from September 2016, and a Class A prediction will be submitted by the Authors as a follow up Technical Note in early 2017. 


\section{Acknowledgements}

This research has been funded under the Australian Research Council (ARC) Linkage scheme as a collaboration among the Universities of Wollongong and Newcastle in Australia and Imperial College of Science, Technology and Medicine, University of London, UK. The

authors acknowledge the support of the industry partners Menard-Bachy, Coffey Geotechnics, Douglas Partners, the National Jute Board of India, and Soilwicks Pty Ltd.

\section{Appendix: Derivation of the analytical solution}

By substituting equations (3) and (4) in equation (9), we have:

$$
\frac{\gamma_{w}}{2 k_{h}} \frac{\partial \varepsilon_{v}}{\partial t} \frac{1}{r_{i}}\left[\left(r_{i}-\frac{S}{2}\right)^{2}-r_{i}^{2}+\left(r_{i}+\frac{S}{2}\right)^{2}-r_{i}^{2}\right]+\frac{q_{w}}{2 \pi r_{i} k_{h}}\left(\frac{\partial^{2} u}{\partial z^{2}}\right)_{r=r_{i}}=0
$$

Therefore:

$$
\left(\frac{\partial^{2} u}{\partial z^{2}}\right)_{r=r_{i}}=-\frac{\pi \gamma_{w} S^{2}}{2 q_{w}} \frac{\partial \varepsilon_{v}}{\partial t}
$$

Integrating equation (A2) in the $z$ direction and subject to the boundary conditions (i) at $z=0, u_{r=r_{i}}=-p_{0}\left(\right.$ applied vacuum pressure), and (ii) at $z=L,(\partial u / \partial z)_{r=r_{i}}=p_{0}\left(1-k_{1}\right) / L$, the excess pore water pressure at $r=r_{i}$ can be determined by:

$$
u_{r=r_{i}}=-\frac{\pi \gamma_{w} S^{2}}{4 q_{w}} \frac{\partial \varepsilon_{v}}{\partial t}\left(z^{2}-2 z L\right)-p_{0}\left[1-\left(1-k_{1}\right) \frac{z}{L}\right]
$$

Integrating equations (3) and (4) in the radial direction with the boundary conditions given in equation (A3), $u_{1}$ and $u_{2}$ can be expressed as: 


$$
\begin{aligned}
& u_{1}=\frac{\gamma_{w}}{2 k_{h}} \frac{\partial \varepsilon_{v}}{\partial t}\left[\left(r_{i}-\frac{S}{2}\right)^{2} \ln \left(\frac{r}{r_{i}}\right)-\frac{1}{2}\left(r^{2}-r_{i}^{2}\right)-\frac{k_{h} \pi S^{2}}{2 q_{w}}\left(z^{2}-2 z L\right)\right] \\
& -p_{0}\left[1-\left(1-k_{1}\right) \frac{z}{L}\right]
\end{aligned}
$$

where $r_{i}-S / 2 \leq r \leq r_{i}$, and

$$
\begin{aligned}
& u_{2}=\frac{\gamma_{w}}{2 k_{h}} \frac{\partial \varepsilon_{v}}{\partial t}\left[\left(r_{i}+\frac{S}{2}\right)^{2} \ln \left(\frac{r}{r_{i}}\right)-\frac{1}{2}\left(r^{2}-r_{i}^{2}\right)-\frac{k_{h} \pi S^{2}}{2 q_{w}}\left(z^{2}-2 z L\right)\right] \\
& -p_{0}\left[1-\left(1-k_{1}\right) \frac{z}{L}\right]
\end{aligned}
$$

for $r_{i} \leq r \leq r_{i}+S / 2$

The average excess pore pressure $\bar{u}$ is determined from:

$$
\bar{u} \pi L\left[\left(r_{i}+S / 2\right)^{2}-\left(r_{i}-S / 2\right)^{2}\right]=\int_{0}^{L} \int_{r_{i}-S / 2}^{r_{i}} 2 \pi u_{1} r d r d z+\int_{0}^{L} \int_{r_{i}}^{r_{i}+S / 2} 2 \pi u_{2} r d r d z
$$

Integrating equation (A6) after substituting equations (A4) and (A5), the average excess pore water pressure can be determined by the following:

$$
\begin{aligned}
\bar{u}= & \frac{\gamma_{w}}{k_{h}} \frac{\partial \varepsilon_{v}}{\partial t} \frac{S^{2}}{8 i}\left[-2 i^{3}-1.5 i+2(i-0.5)^{4} \ln \left(\frac{i}{i-0.5}\right)\right. \\
& \left.+2(i+0.5)^{4} \ln \left(\frac{i+0.5}{i}\right)+\frac{4 k_{h} \pi L^{2} i}{3 q_{w}}\right]-\frac{p_{o}}{2}\left(1+k_{1}\right)
\end{aligned}
$$




\section{References}

Barron, R. A. 1948. Consolidation of fine-grained soils by drain wells. Transactions of American Society of Civil Engineers, Paper No. 2346, 113, 718-742.

Bathe, K. 1982. Finite element analysis in engineering analysis. Prentice-Hall.

Belotserkovets, A. \& Prevost, J. H. 2011. Thermoporoelastic response of a fluidsaturated porous sphere: An analytical solution. International Journal of Engineering Science, 49, 1415-1423.

Bergado, D., Mukherjee, K., Alfaro, M. \& Balasubramaniam, A. 1993. Prediction of vertical-band-drain performance by the finite-element method. Geotextiles and Geomembranes, 12, 567-586.

Brinkgreve, R., Kumarswamy, S. \& Swolfs, W. (eds.) 2015. PLAXIS 2D 2015, User's Manual, Netherlands: Plaxis bv.

Casagrande, L. \& Poulos, S. 1969. On the effectiveness of sand drains. Canadian Geotechnical Journal, 6, 287-326.

Chai, J.-C., Carter, J. \& Hayashi, S. 2006. Vacuum consolidation and its combination with embankment loading. Canadian Geotechnical Journal, 43, 985-996.

Chai, J. \& Carter, J. P. 2011. Deformation analysis in soft ground improvement, Springer Science \& Business Media.

Dam, T. K. L., Sandanbata, I. \& Kimura, M. 2006. Vacuum Consolidation MethodWorldwide Practice and the Latest Improvement in Japan.

Gabr, M. \& Szabo, D. J. 1997. Prefabricated vertical drains zone of influence under vacuum in clayey soil. In: EVANS, J. C. (ed.) In Situ Remediation of the Geoenvironment. Minneapolis, Minnesota: American Society of Civil Engineers, Reston, VA (United States).

Hansbo, S. 1997. Aspects of vertical drain design: Darcian or non-Darcian flow. Geotechnique, 47, 983-992.

Hird, C., Pyrah, I. \& Russel, D. 1992. Finite element modelling of vertical drains beneath embankments on soft ground. Geotechnique, 42, 499-511.

Holtz, R. D., Jamiolkowski, M., Lancellotta, R. \& Pedroni, R. 1991. Prefabricated vertical drains: design and performance, London, Construction Industry Research \& Information Assoc.

Indraratna, B., Aljorany, A. \& Rujikiatkamjorn, C. 2008. Analytical and numerical modeling of consolidation by vertical drain beneath a circular embankment. International Journal of Geomechanics, 8, 199-206.

Indraratna, B., Balasubramaniam, A. \& Balachandran, S. 1992. Performance of test embankment constructed to failure on soft marine clay. Journal of Geotechnical Engineering, ASCE, 118, 12-33.

Indraratna, B. \& Chu, J. 2005. Ground Improvement-Case Histories, London, UK, Elsevier. 
Indraratna, B., Perera, D., Rujikiatkamjorn, C. \& Kelly, R. 2014. Soil disturbance analysis due to vertical drain installation. Proceedings of the Institution of Civil Engineers - Geotechnical Engineering, 168, 236-246.

Indraratna, B. \& Redana, I. 1997. Plane-strain modeling of smear effects associated with vertical drains. Journal of Geotechnical and Geoenvironmental Engineering, 123, 474-478.

Indraratna, B. \& Redana, I. 1998. Laboratory determination of smear zone due to vertical drain installation. Journal of geotechnical and geoenvironmental engineering, 124, $180-184$.

Indraratna, B. \& Redana, I. 2000. Numerical modeling of vertical drains with smear and well resistance installed in soft clay. Canadian Geotechnical Journal, 37, 132145.

Indraratna, B., Rujikiatkamjorn, C., Ameratunga, J. \& Boyle, P. 2011. Performance and prediction of vacuum combined surcharge consolidation at Port of Brisbane. Journal of Geotechnical and Geoenvironmental Engineering, 137, 1009-1018.

Indraratna, B., Rujikiatkamjorn, C., Kelly, R. \& Buys, H. 2012. Soft soil foundation improved by vacuum and surcharge loading. Proceedings of the ICE-Ground Improvement, 165, 87-96.

Indraratna, B., Rujikiatkamjorn, C. \& Sathananthan, I. 2005. Analytical and numerical solutions for a single vertical drain including the effects of vacuum preloading. Canadian Geotechnical Journal, 42, 994-1014.

Kelly, R., O’loughlin, C., Bates, L., Gourvenec, S., Colreavy, C., White, D., Gaone, F., Doherty, J. \& Randolph, M. 2014. In situ testing at the National Soft Soil Field Testing Facility, Ballina. New South Wales. Australian Geomechanics, 49, 15-26.

Kianfar, K., Indraratna, B., Rujikiatkamjorn, C. \& Leroueil, S. 2015. Radial consolidation response upon the application and removal of vacuum and fill loading. Canadian Geotechnical Journal, 52, 2156-2162.

Kjellman, W. 1952. Consolidation of clayey soils by atmospheric pressure. Proceedings of a Conference on Soil Stabilization. Boston: MIT Press.

Li, J. H., Huang, J., Cassidy, M. J. \& Kelly, R. 2014. Spatial variability of the soil at the Ballina National Field Test Facility. Australian Geomechanics, 49, 41-48.

Mohamedelhassan, E. \& Shang, J. 2002. Vacuum and surcharge combined onedimensional consolidation of clay soils. Canadian Geotechnical Journal, 39, 1126-1138.

Pariseau, W. 1999. Poroelastic - plastic consolidation-analytical solution. International journal for numerical and analytical methods in geomechanics, 23, 577-594.

Parsa-Pajouh, A., Fatahi, B., Vincent, P. \& Khabbaz, H. 2014. Trial Embankment Analysis to Predict Smear Zone Characteristics Induced by Prefabricated Vertical Drain Installation. Geotechnical and Geological Engineering, 32, 1187-1210.

Pineda, J., Suwal, L. \& Kelly, R. 2014. Sampling and laboratory testing of Ballina clay. Australian Geomechanics, 49, 27-40.

Pineda, J., Suwal, L., Kelly, R., Bates, L. \& Sloan, S. 2016. Characterisation of Ballina clay. Géotechnique, 1-22. 
Richart, F. E., Jr. 1957. A review of the theories for sand drains. Journal of the Soil Mechanics and Foundations Division, ASCE, 83, 1-38.

Rixner, J., Kraemer, S. \& Smith, A. D. 1986. Prefabricated vertical drains: Engineering guidelines, FWHA/RD-86/168, Washington DC, Federal Highway Administration.

Selvadurai, A. \& Suvorov, A. Boundary heating of poro-elastic and poro-elasto-plastic spheres. Proceedings of the Royal Society of London A: Mathematical, Physical and Engineering Sciences, 2012. The Royal Society, 2779-2806.

Selvadurai, A. \& Suvorov, A. Thermo-poromechanics of a fluid-filled cavity in a fluidsaturated geomaterial. Proceedings of the Royal Society of London A: Mathematical, Physical and Engineering Sciences, 2014. The Royal Society. 


\section{List of Tables}

TABLE 1: SELECTED STIFFNESS AND STRENGTH MATERIAL PARAMETERS FOR BALLINA SITE

TABLE 2: MATERIAL PARAMETERS SELECTED FOR SIMULATION OF FILL EMBANKMENT ...

TABLE 3: EFFECT OF SMEAR ZONE ON EXPECTED TERMINATION OF VACUUM ..... 
Table 1: Selected stiffness and strength material parameters for Ballina site

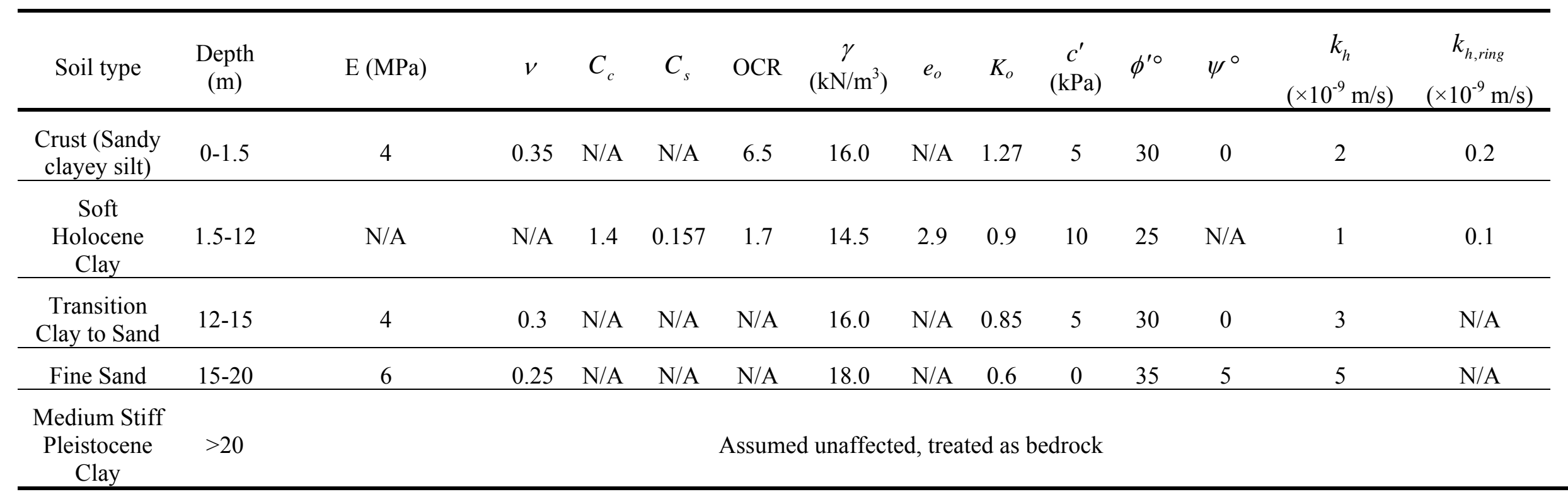

E: Elastic modulus, $v$ : Poison's ratio, $C_{c}$ : Compression index, in $e-\log \sigma^{\prime}$ plane, $C_{s}$ : Swelling index in $e-\log \sigma^{\prime}$ plane, OCR: Over-consolidation ratio, $\gamma$ : Saturated unit weight, $e_{o}$ : Initial void ratio, $K_{o}$ : Coefficient of lateral pressure at-rest, $c^{\prime}$ : Drained cohesion, $\phi^{\prime}:$ Drained friction angle, $\psi:$ Dilation angle, $k_{h}$ : Coefficients of permeability in horizontal direction, and $k_{h, \text { ring }}$ : Equivalent coefficients of permeability for converted drain wall 
Table 2: Material parameters selected for simulation of fill embankment

\begin{tabular}{cccccc}
\hline Fills layer & $\mathrm{E}(\mathrm{MPa})$ & $v$ & $\gamma\left(\mathrm{kN} / \mathrm{m}^{3}\right)$ & $c^{\prime}(\mathrm{kPa})$ & $\phi^{\prime \circ}$ \\
\hline 1 (Working platform) & 6 & 0.3 & 16 & 0 & 30 \\
\hline 2 (Sand Blanket) & 7 & 0.3 & 17 & 0 & 32 \\
\hline 3 (Final fill) & 8 & 0.3 & 18 & 5 & 35 \\
\hline
\end{tabular}


Table 3: Effect of smear zone on expected termination of vacuum

\begin{tabular}{cccc}
\hline & \multicolumn{4}{c}{$\mathrm{k}_{\mathrm{h}} / \mathrm{k}_{\mathrm{s}}$} \\
\cline { 2 - 4 } & 1.5 & 3 & 5 \\
\cline { 2 - 4 } $\mathrm{d}_{\mathrm{s}} / \mathrm{d}_{\mathrm{w}}$ & \multicolumn{4}{c}{ Time to achieve zero excess pore pressure (days) } \\
\hline 2 & 38 & 51 & 66 \\
\hline 4 & 42 & 66 & 101 \\
\hline 6 & 44 & 76 & 121 \\
\hline
\end{tabular}




\section{List of Figures}

FIGURE 1: CONVERSION FOR MULTIDRAIN SYSTEM UNDER CIRCULAR LOADING ADOPTED FOR ANALYTICAL SOLUTIONS IN (A) SQUARE PATTERN, (B) TRIANGULAR PATTERN, AND (C) ELEVATION VIEW OF A SINGLE RING

FIGURE 2: (A) A SINGLE HOLLOW CYLINDER OF SOIL-DRAIN, (B) VERTICAL CROSS SECTION OF A DRAIN WALL AND FLOW CONDITION IN VERTICAL DIRECTION, (C) DISTRIBUTION OF VACUUM PRESSURE IN ANALYTICAL MODEL 36

Figure 3: VARIATION OF $\mu_{\text {ring }} / \alpha^{2}$ With $i$ 37

FIGURE 4: FINITE ELEMENT DISCRETIZATION FOR AN AXISYMMETRIC DRAIN RING: (A) NODES AND INTEGRATION POINTS FOR A SINGLE 6-NODE ELEMENT; (B) MESH DISCRETIZATION, BOUNDARY CONDITIONS, AND VACUUM PRESSURE DISTRIBUTION FOR A SINGLE DRAIN RING (MESH SHOWN FOR L=10 M)

Figure 5: Results of Simulations of single Ring of Sydney Clay in (A) CASE A: L=10 M, $K_{1}=1.0$, AND (B) CASe B: L=50 M, $\mathrm{K}_{1}=0.5$, IN COMPARISON WITH ANALYTICAL SOLUTIONS

Figure 6: (A) PLAN, AND (B) TYPICAL CROSS SECTION OF CIRCULAR VP EMBANKMENT IN BFTF. 40

FIGURE 7: MESH, BOUNDARY CONDITIONS AND CONTROL POINTS OF THE VP CIRCULAR EMBANKMENT 41

FIGURE 8: ASSUMED TIME HISTORY OF EMBANKMENT CONSTRUCTION AND APPLICATION OF VACUUM: (A) VACUUM AND SURCHARGE OF 3.5 M HIGH FILL, AND (B) NO VACUUM AND SURCHARGE OF 7.5 M HIGH FILL 42

Figure 9: SETtLeMENT PATtern OF THE GROUND SURFACE BENEATH VP CIRCULAR EMBANKMENT WITH AND WITHOUT VACUUM .. 43

FIGURE 10: COMPARISON BETWEEN NON-VACUUM AND VACUUM CONSOLIDATION OF CIRCULAR EMBANKMENT: (A) SETTLEMENT, AND (B) EXCESS PORE PRESSURE TIME HISTORIES.

FiguRE 11: CONTOURS OF HORIZONTAL DISPLACEMENTS, AFTER ONE YEAR VP CONSOLIDATION

Figure 12: PROFILES OF HORIZONTAL DISPLACEMENTS AT THE TOE OF CIRCULAR EMBANKMENT ( $X=14.4 \mathrm{M})$.

FIGURE 13: TIME HISTORIES OF HORIZONTAL DISPLACEMENT IN SELECTED KEY POINTS IN CASE OF CONTINUES VACUUM CONSOLIDATION FOR ONE YEAR.

Figure 14: EFFECT OF VACUUM TERMINATION ON CONSOLIDATION PERFORMANCE: (A) EXCESS PORE PRESSURE, AND (B) SETTLEMENT TIME HISTORIES.

FIGURE 15: PROFILE OF PRE-CONSOLIDATION PRESSURE ALONG THE EMBANKMENT CENTRELINE

FIGURE 16: TIME HISTORY OF EXCESS PORE PRESSURE AT THE MIDDLE OF THE SOFT CLAY LAYER FOR A VARIETY OF SMEAR CHARACTERISTICS: (A) $D_{s} / D_{w}=2$, (B) $D_{s} / D_{w}=4$, AND (C) $D_{s} / D_{w}=6$ 50 


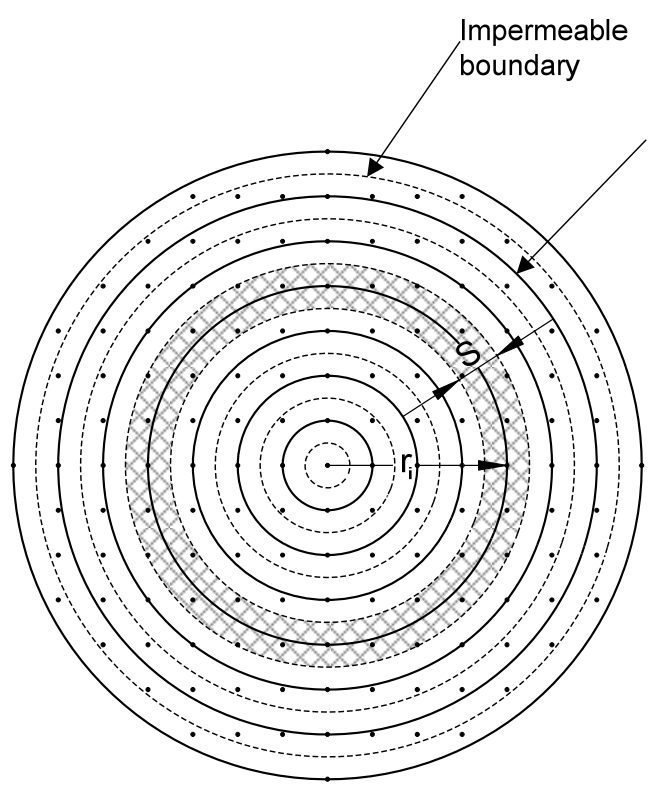

(a)

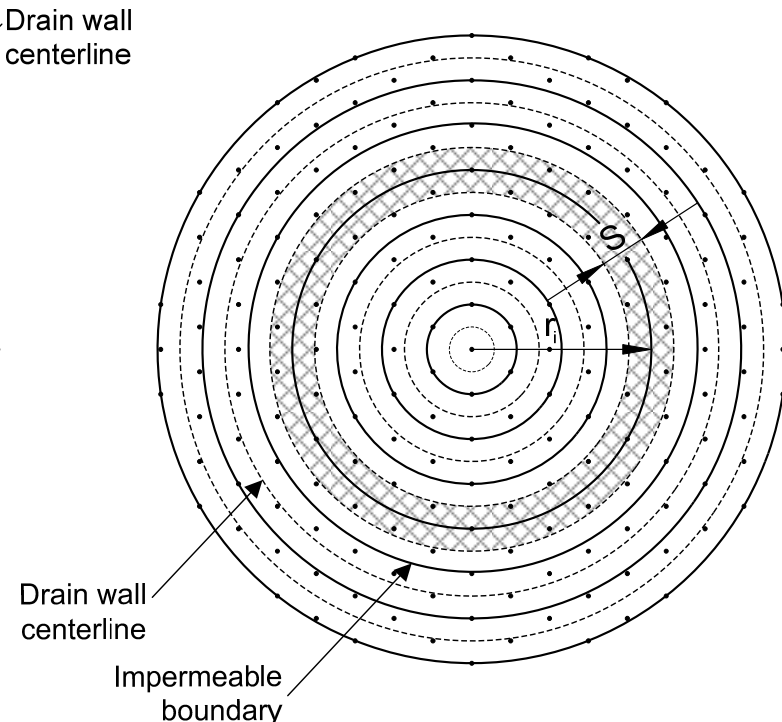

(b)

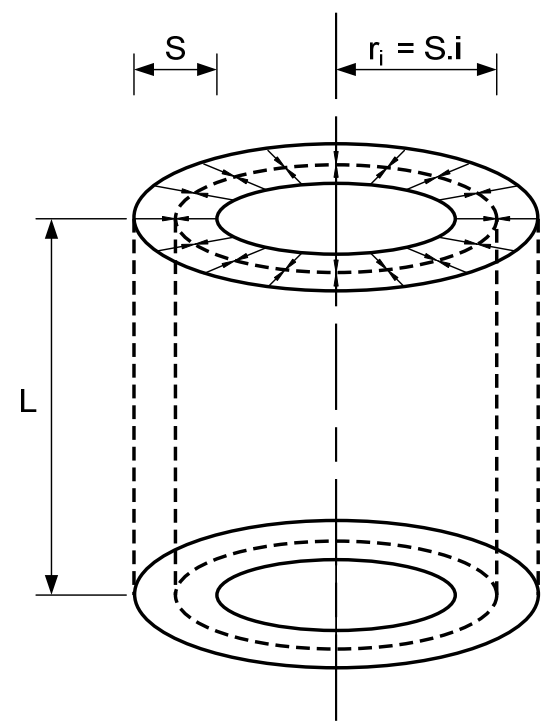

(c)

Figure 1: Conversion for multidrain system under circular loading adopted for analytical solutions in (a) square pattern, (b) triangular pattern, and (c) elevation view of a single ring 


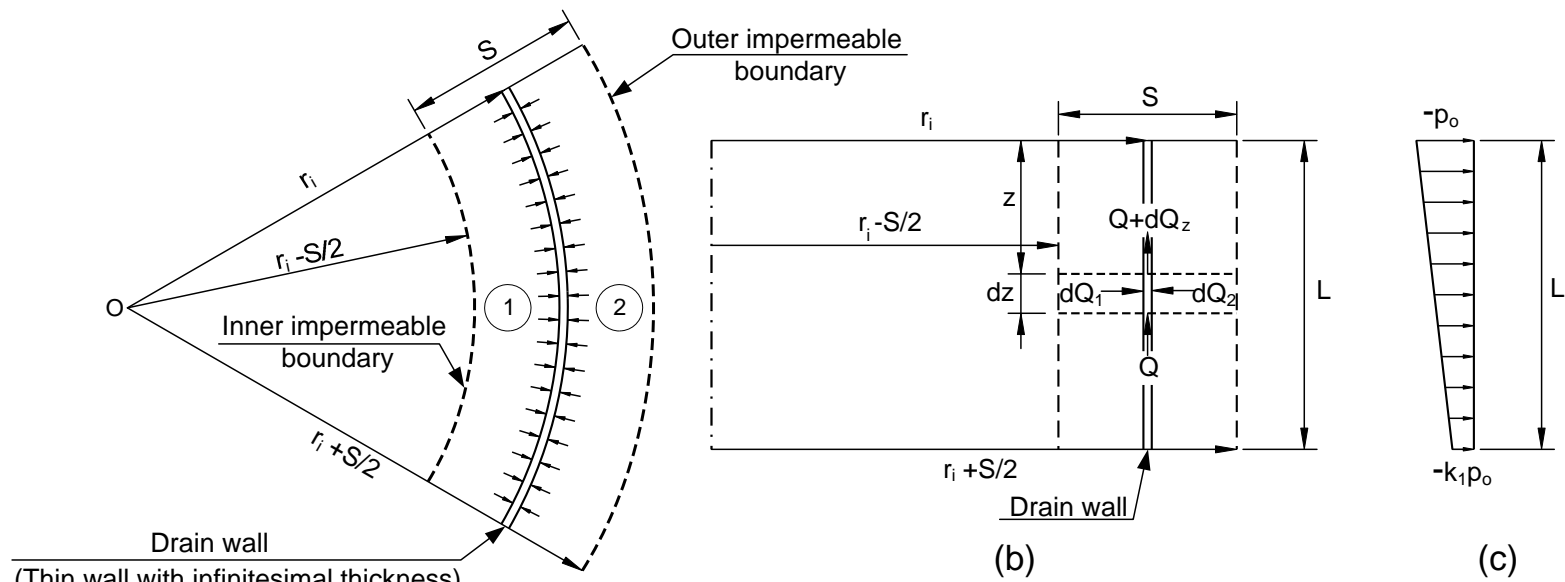

(a)

Figure 2: (a) A single hollow cylinder of soil-drain, (b) vertical cross section of a drain wall and flow condition in vertical direction, (c) distribution of vacuum pressure in analytical model 


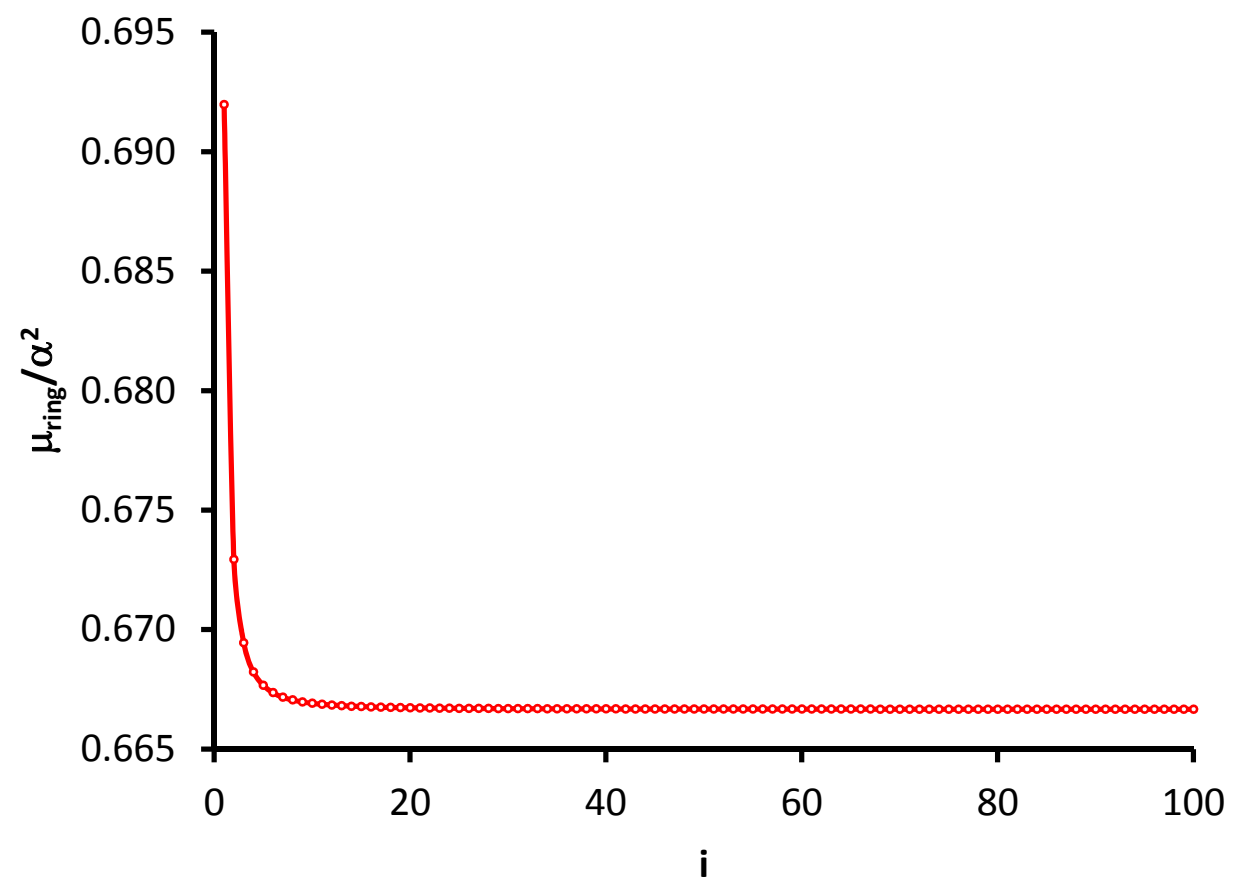

Figure 3: Variation of $\mu_{\text {ring }} / \alpha^{2}$ with $i$ 


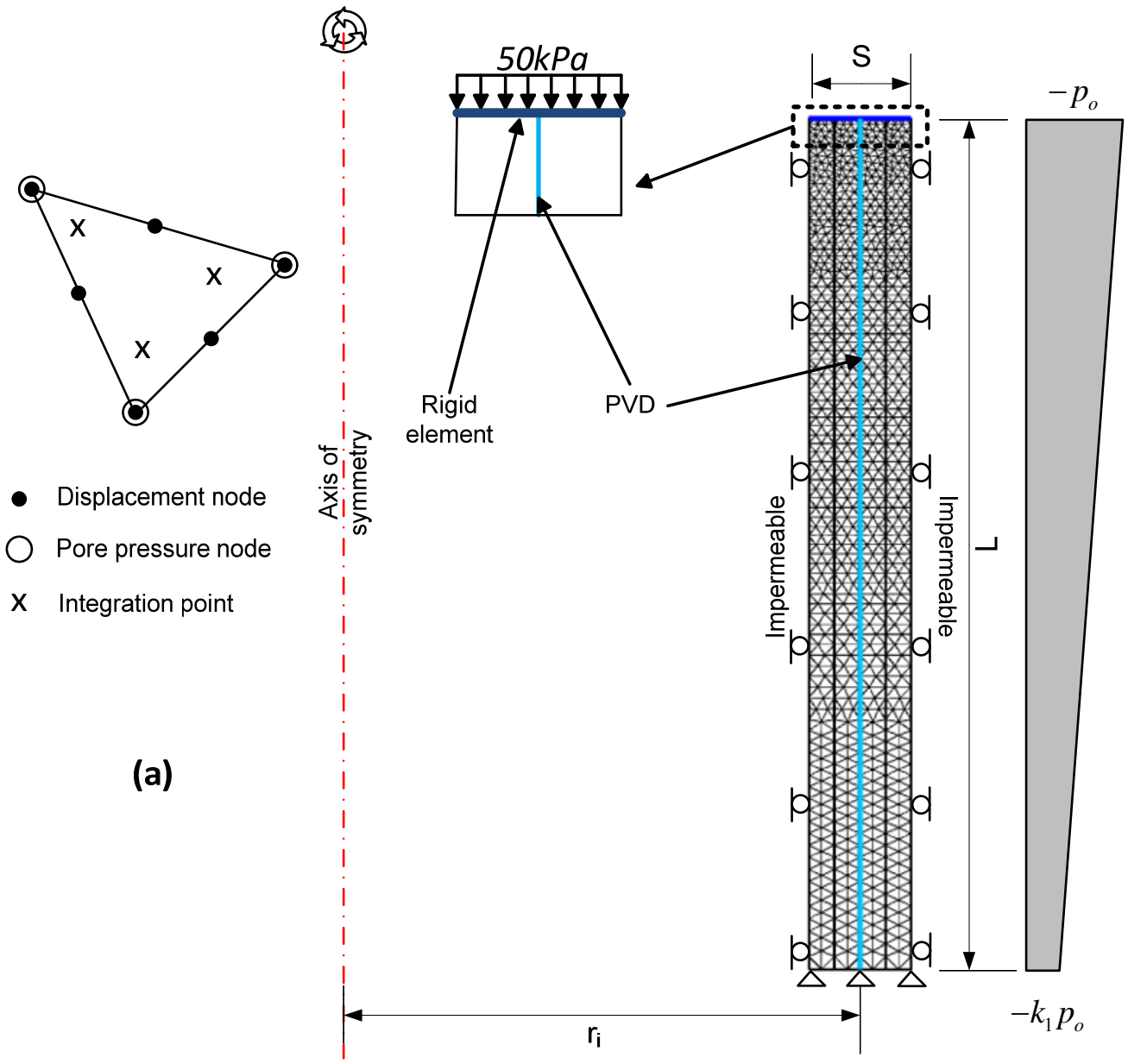

(b)

Figure 4: Finite element discretization for an axisymmetric drain ring: (a) nodes and integration points for a single 6-node element; (b) mesh discretization, boundary conditions, and vacuum pressure distribution for a single drain ring (mesh shown for $L=10 \mathrm{~m}$ ) 


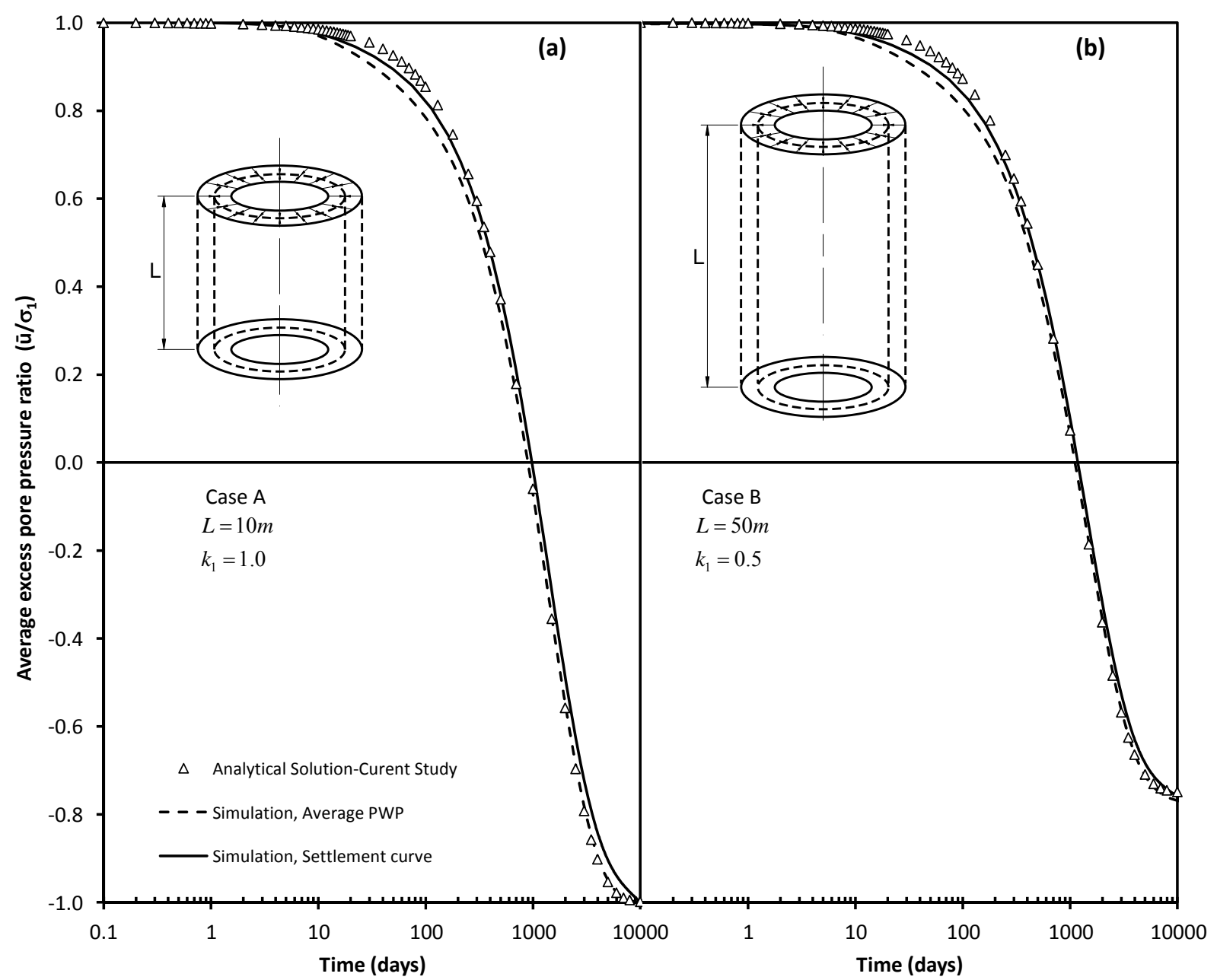

Figure 5: Results of simulations of single ring of Sydney clay in (a) Case $A: L=10 \mathrm{~m}, k_{1}=1.0$, and (b) Case B: $\mathrm{L}=\mathbf{5 0} \mathrm{m}, \mathrm{k}_{\mathbf{1}}=\mathbf{0 . 5}$, in comparison with analytical solutions 


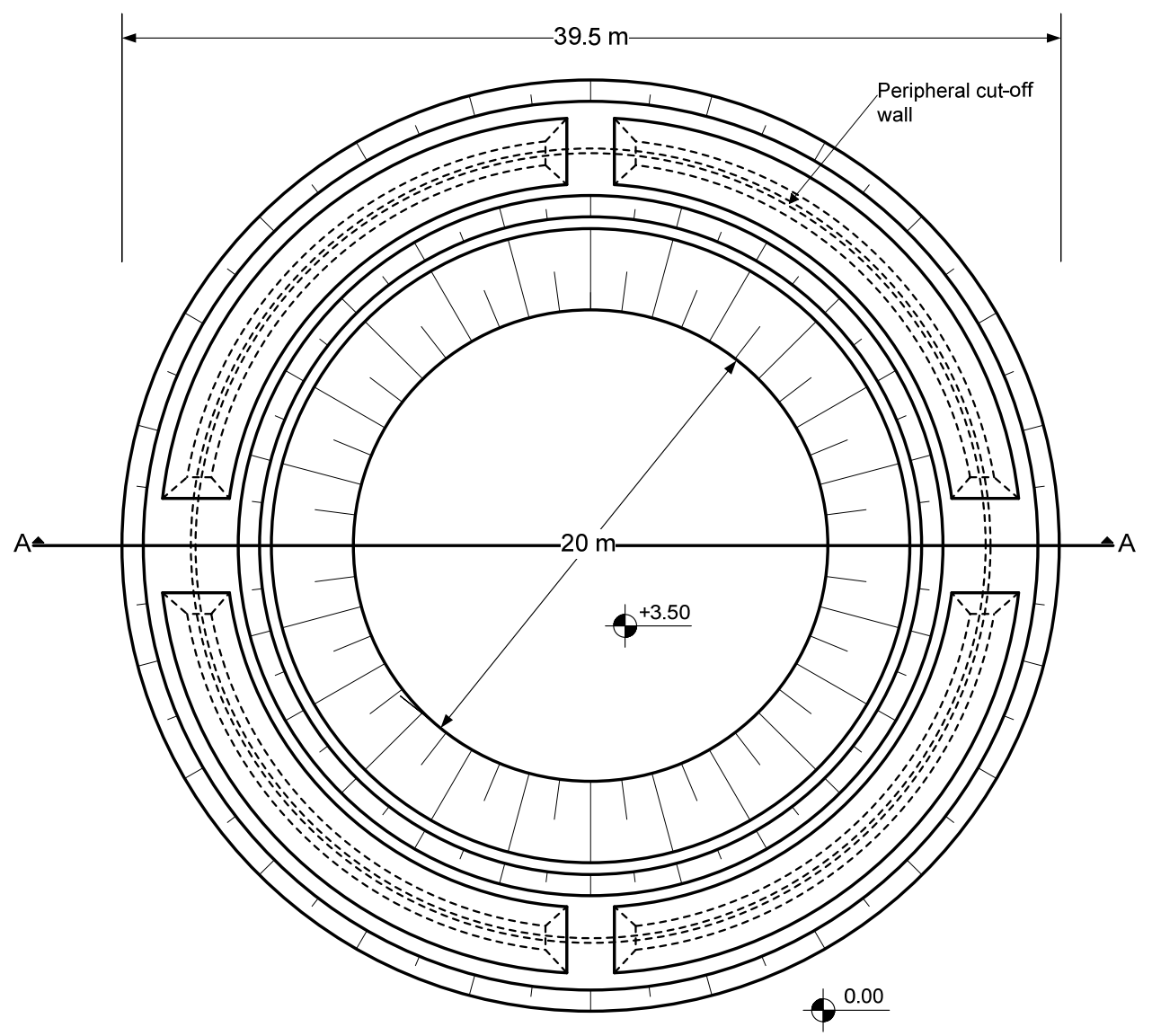

(a)

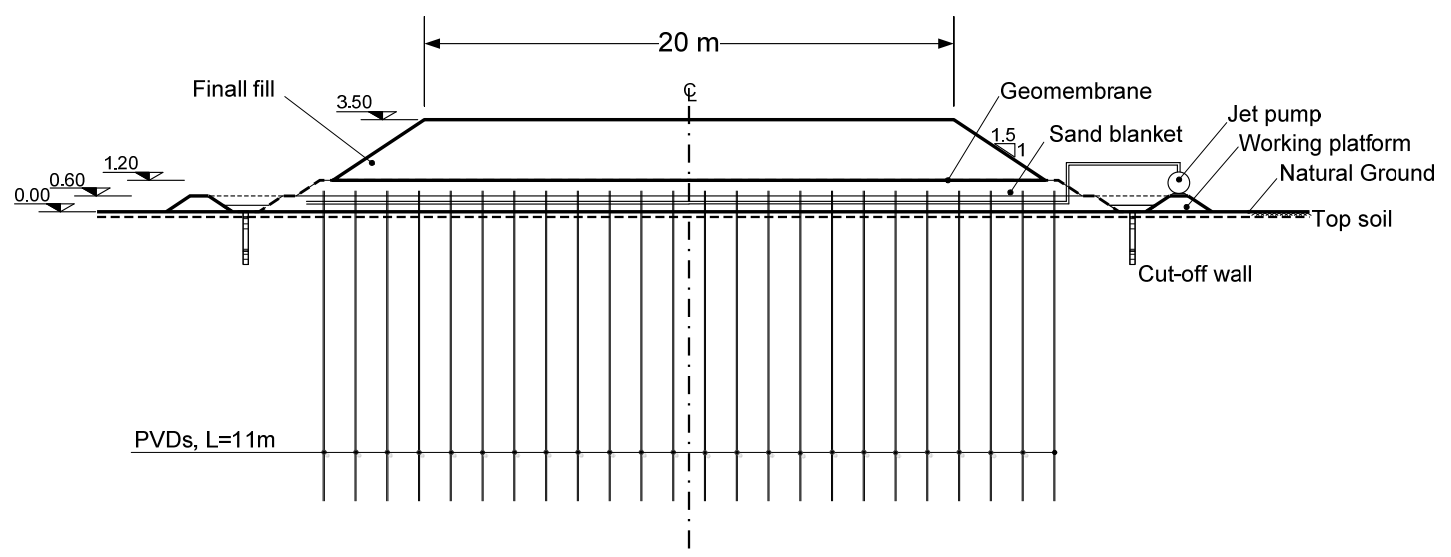

(b)

Figure 6: (a) Plan, and (b) typical cross section of circular VP embankment in BFTF 


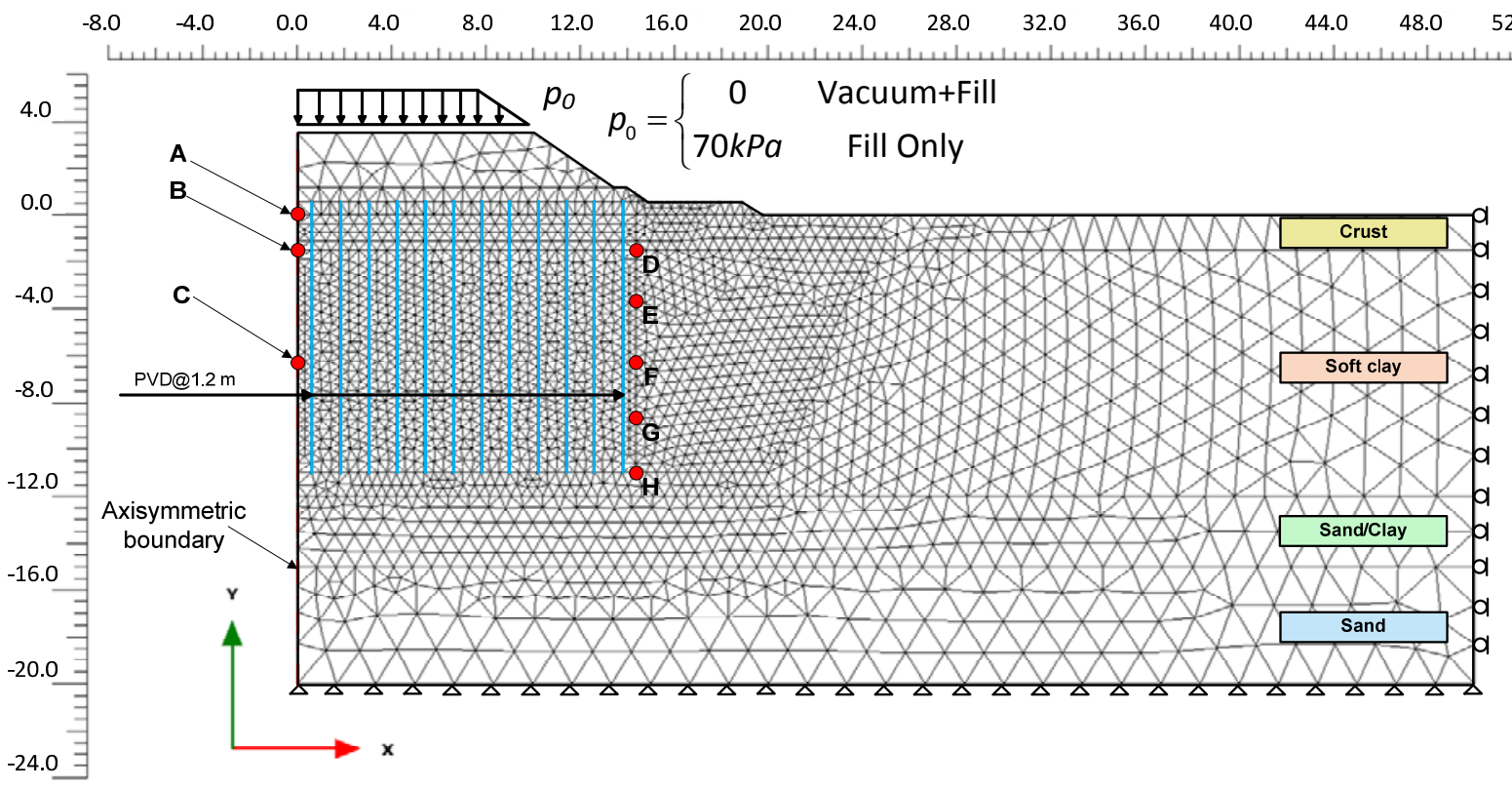

Figure 7: Mesh, boundary conditions and control points of the VP circular embankment 


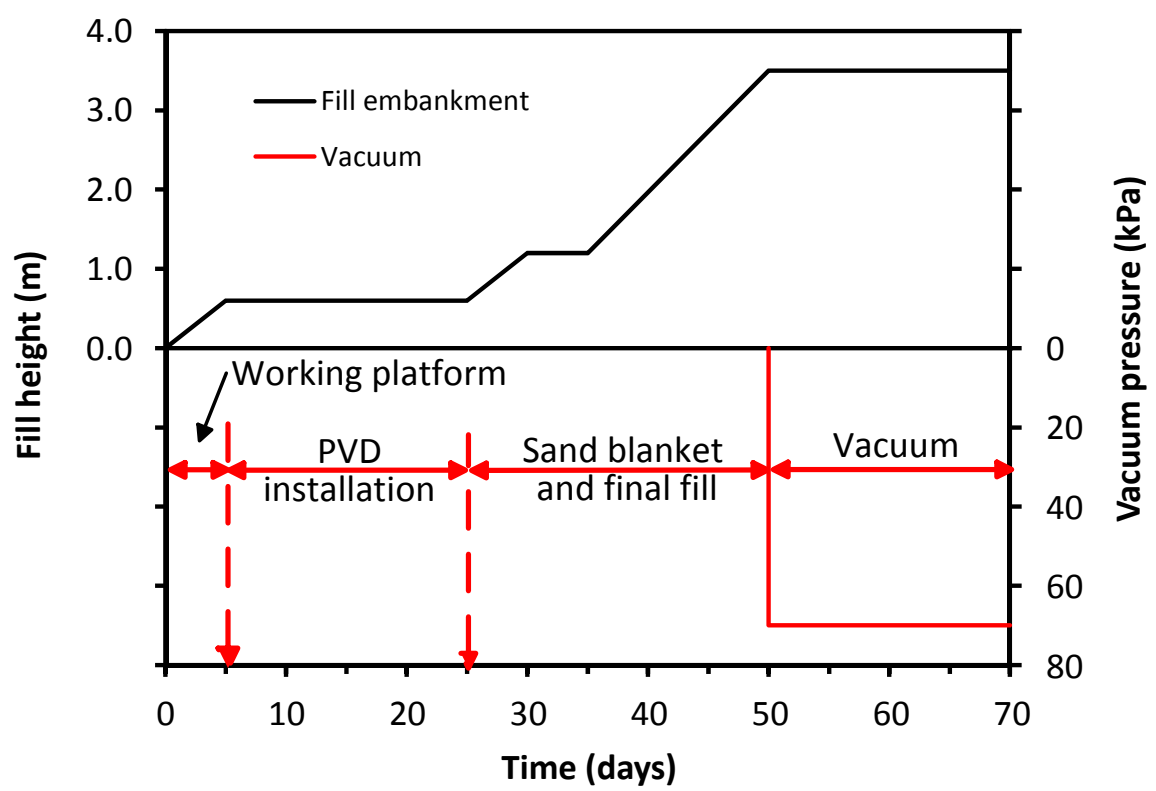

(a)

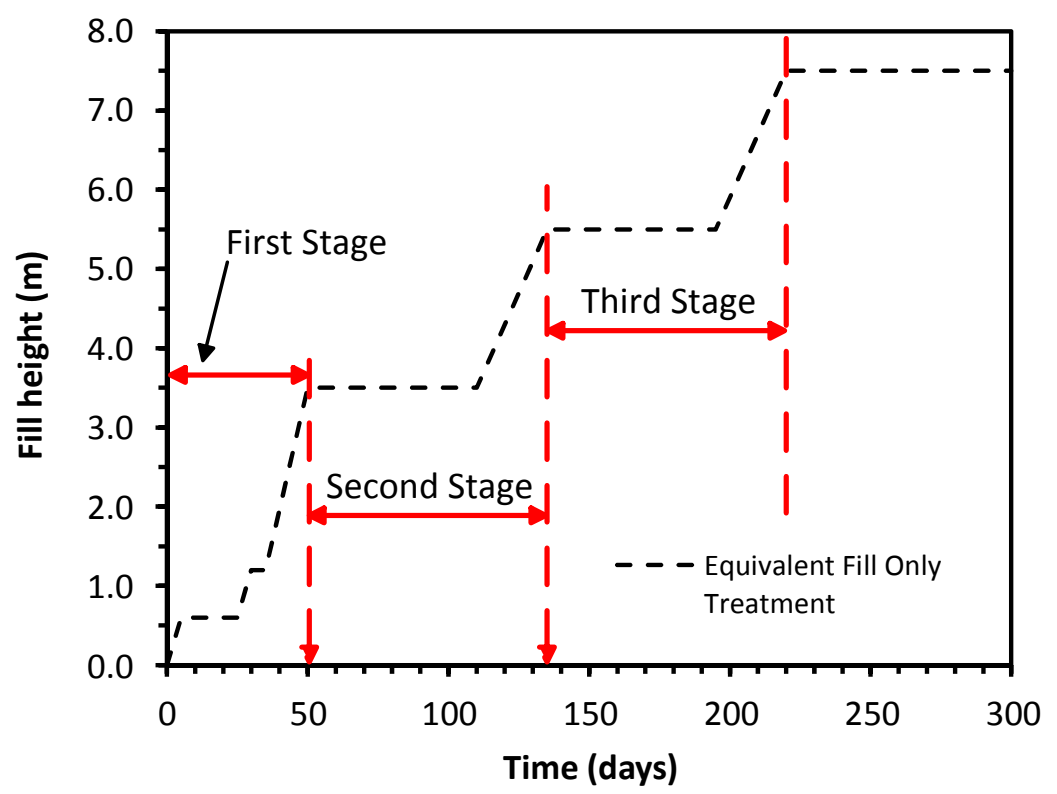

(b)

Figure 8: Assumed time history of embankment construction and application of vacuum:

(a) vacuum and surcharge of $3.5 \mathrm{~m}$ high fill, and (b) no vacuum and surcharge of $7.5 \mathrm{~m}$ high fill 


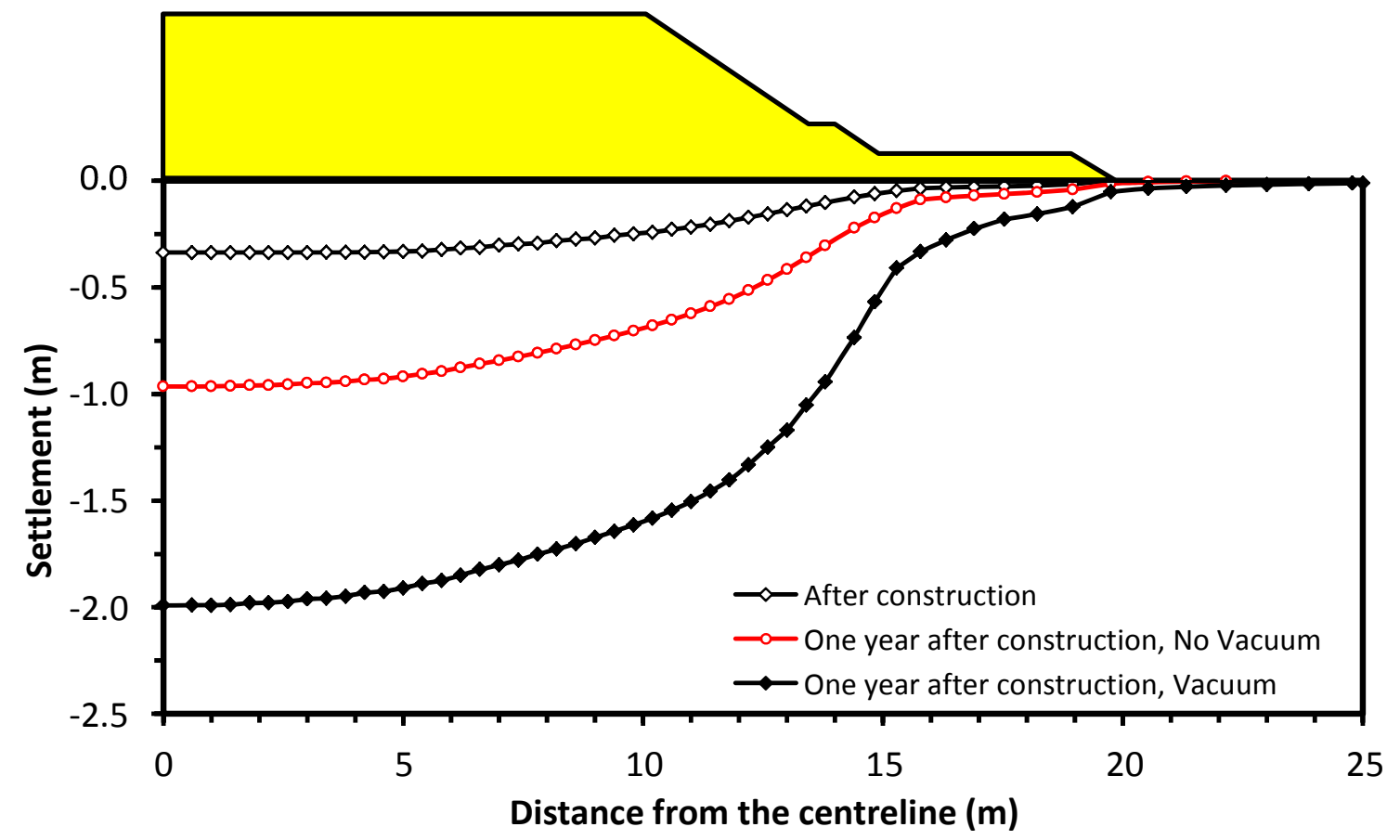

Figure 9: Settlement pattern of the ground surface beneath VP circular embankment with and without vacuum 


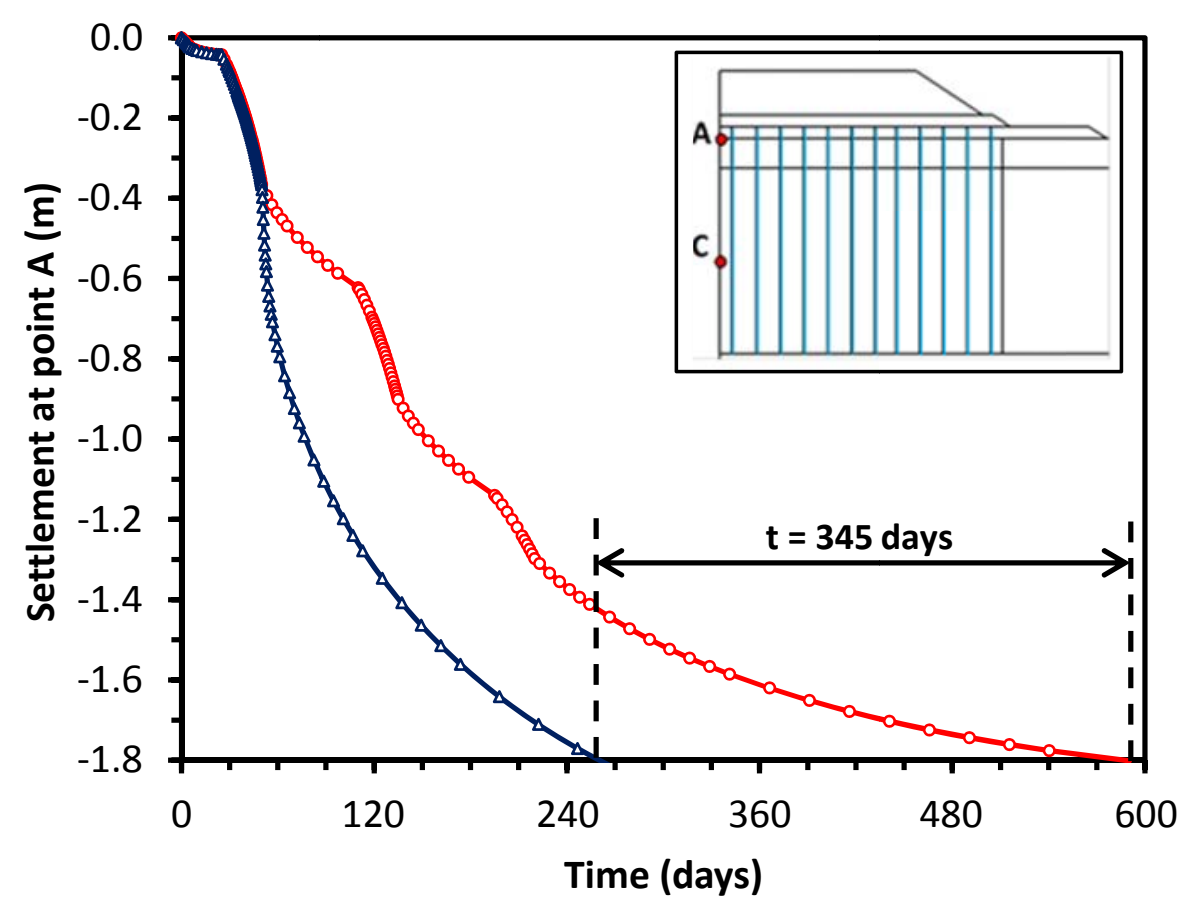

(a)

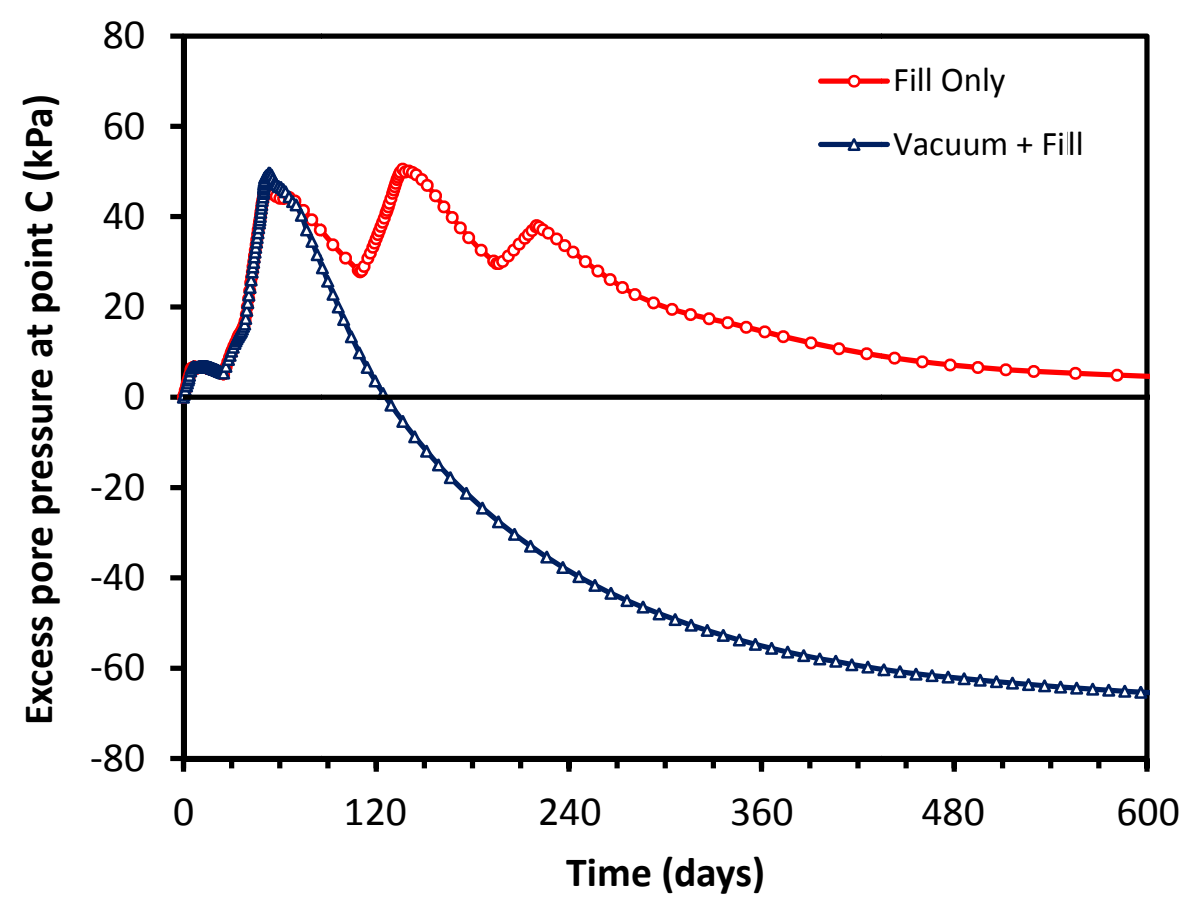

(b)

Figure 10: Comparison between non-vacuum and vacuum consolidation of circular embankment:

(a) settlement, and (b) excess pore pressure time histories 


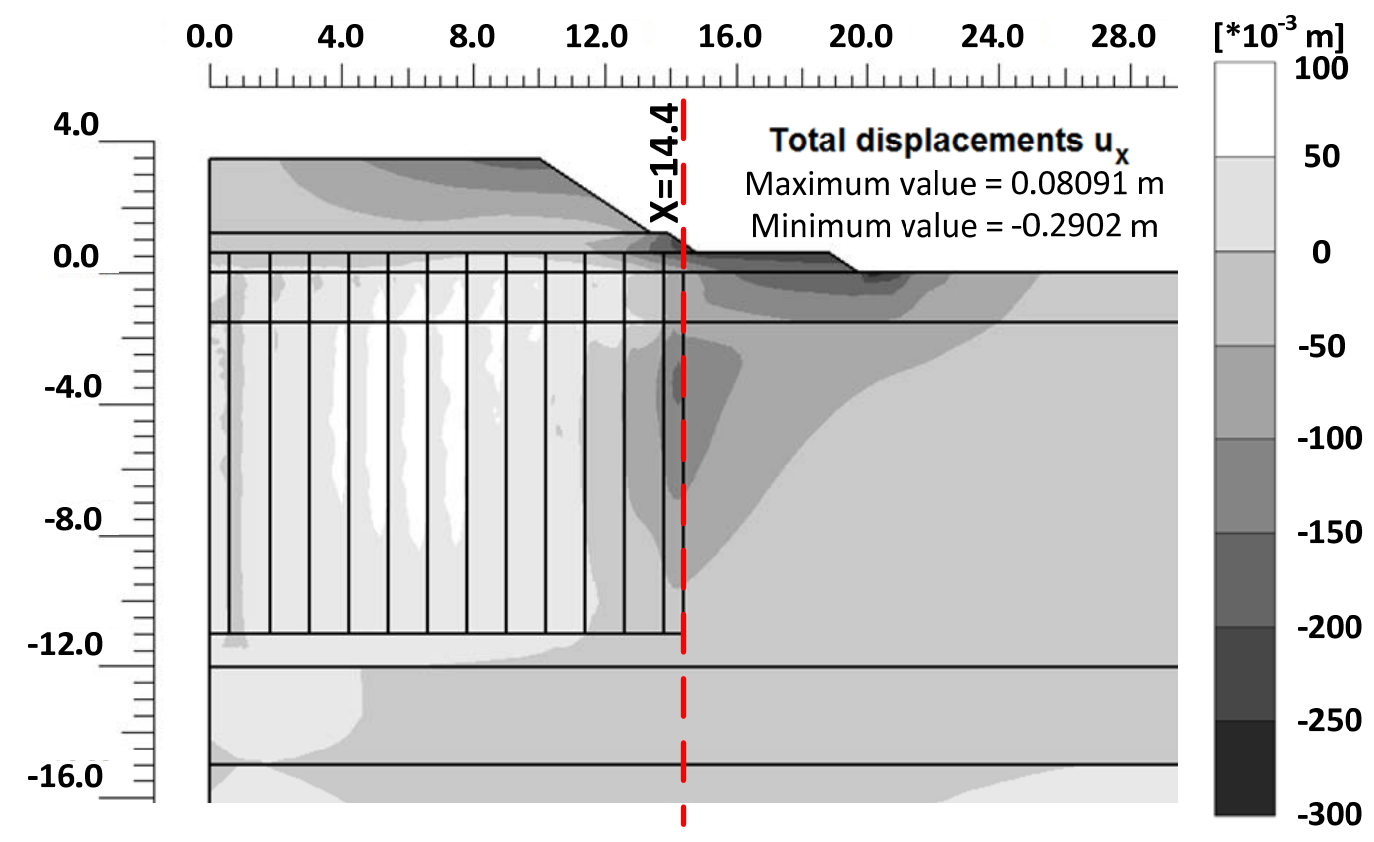

Figure 11: Contours of horizontal displacements, after one year VP consolidation 


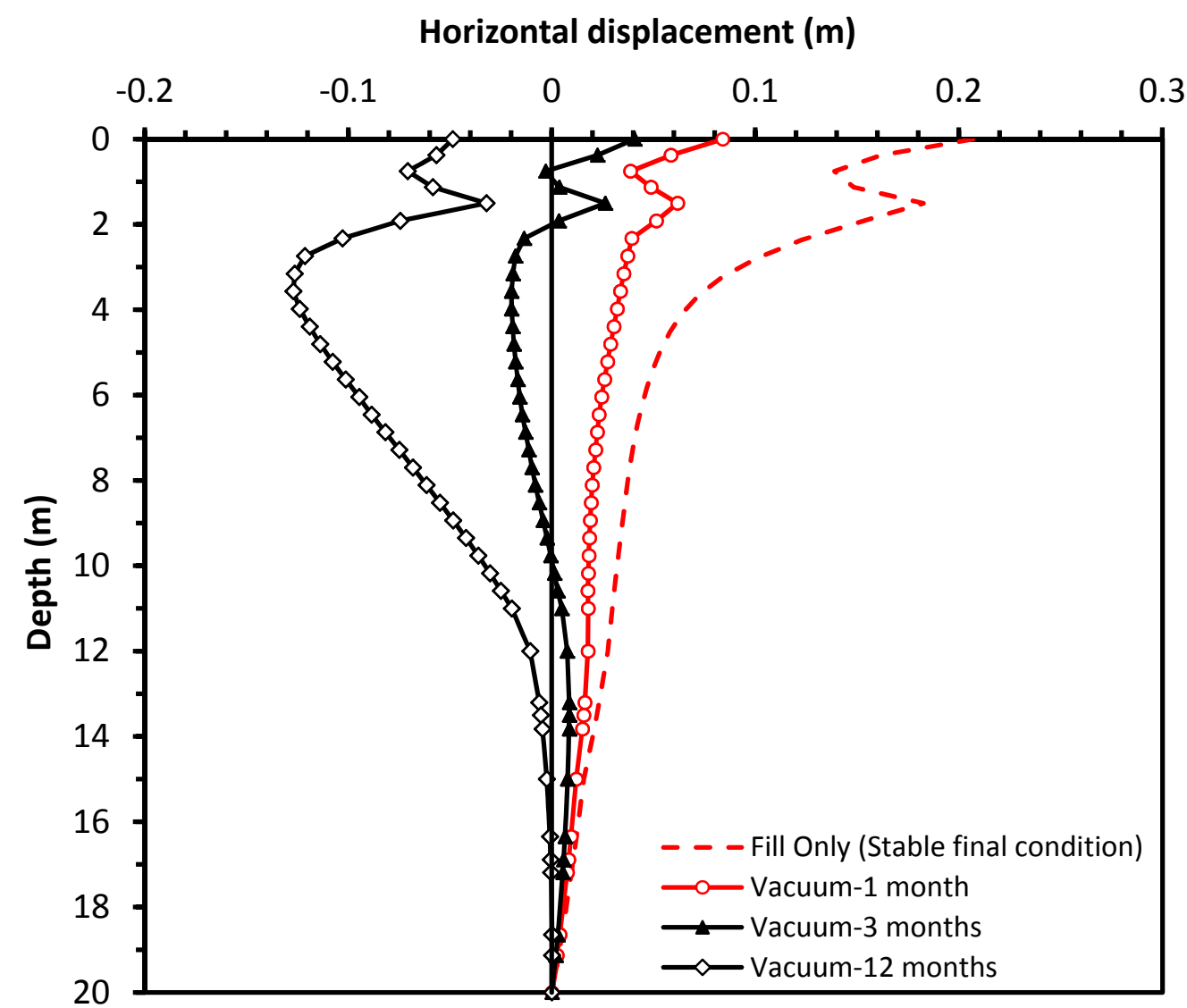

Figure 12: Profiles of horizontal displacements at the toe of circular embankment $(x=14.4 \mathrm{~m})$ 


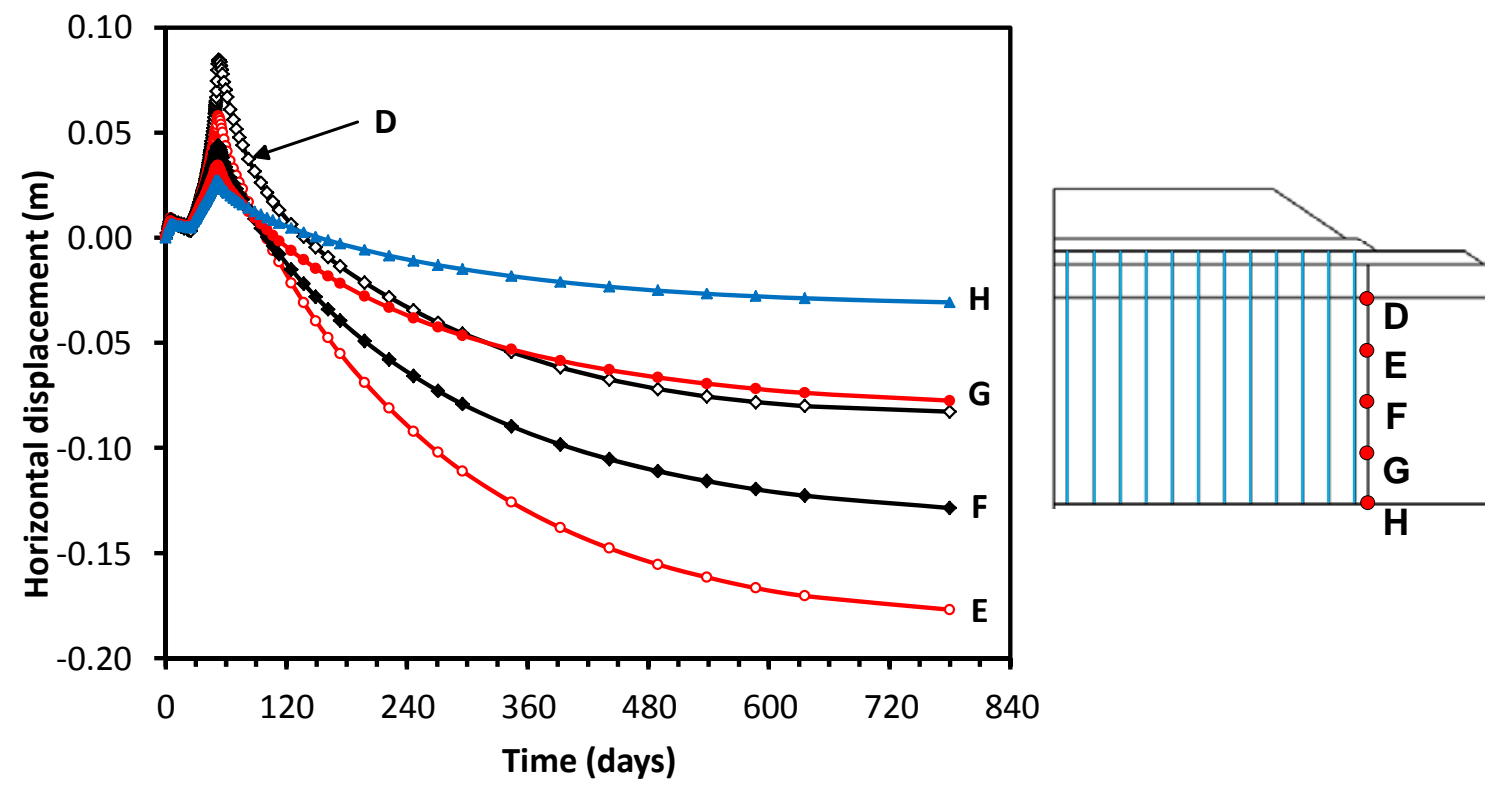

Figure 13: Time histories of horizontal displacement in selected key points in case of continues vacuum consolidation for one year 


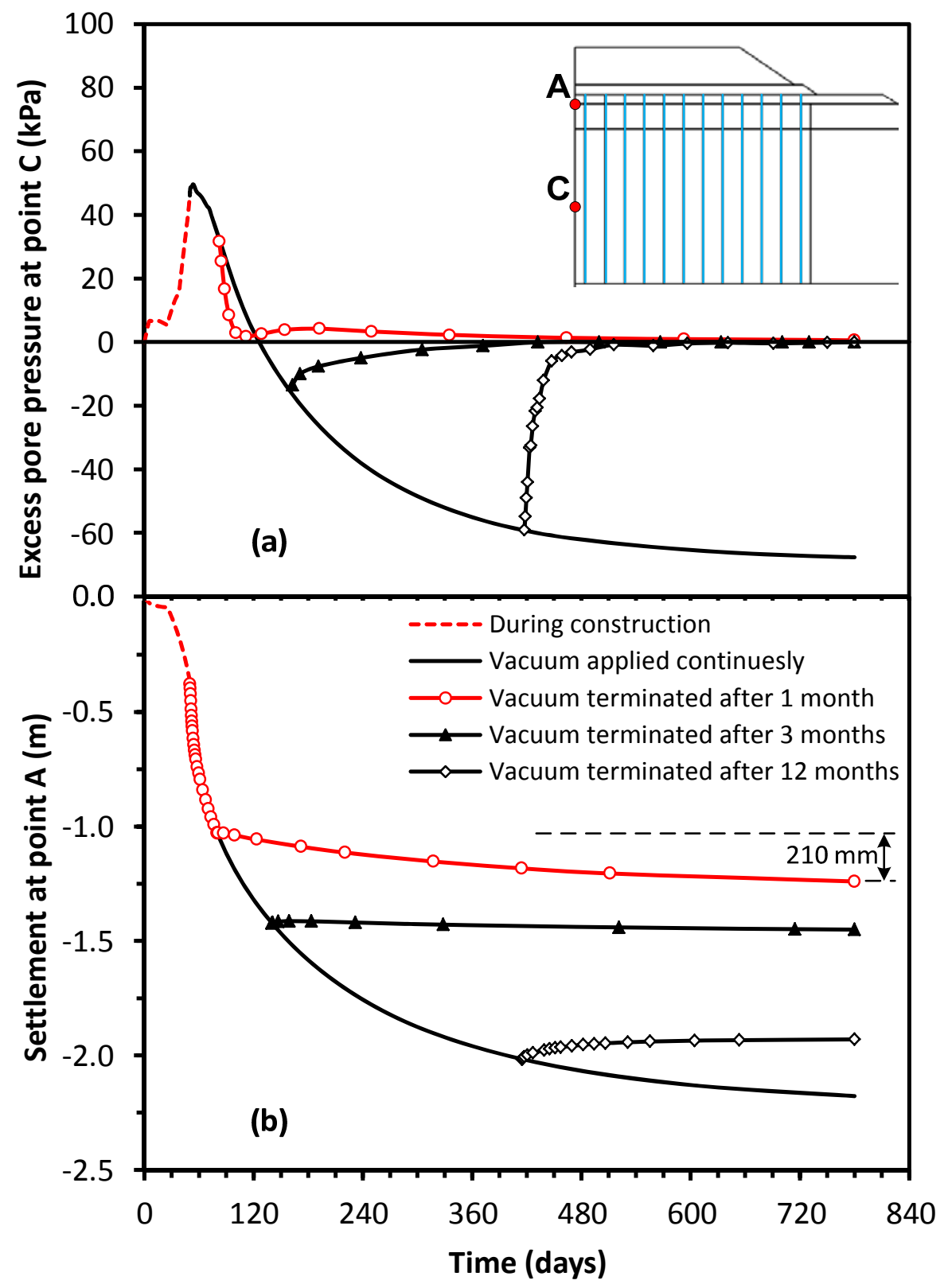

Figure 14: Effect of vacuum termination on consolidation performance:

(a) excess pore pressure, and (b) settlement time histories 


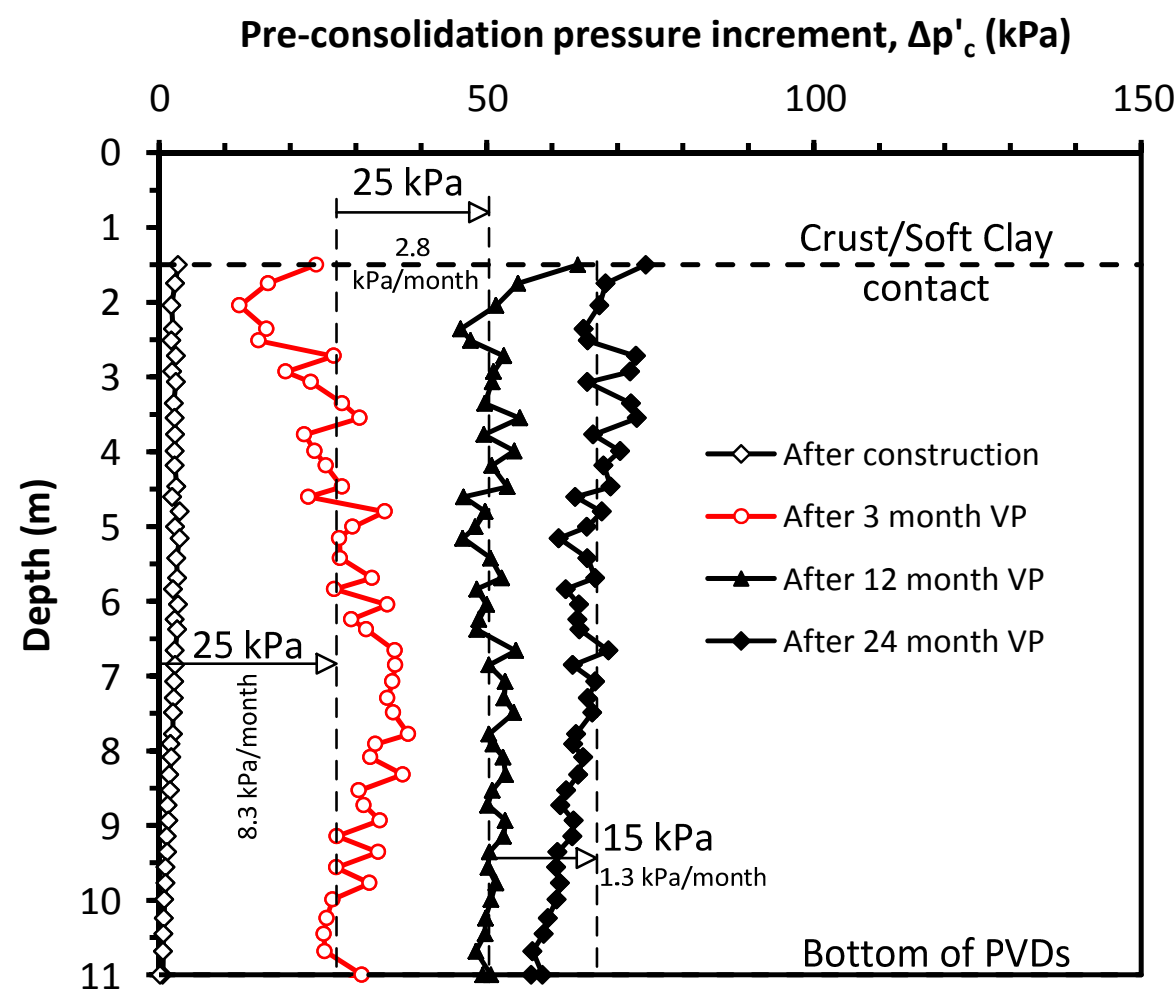

Figure 15: Profile of pre-consolidation pressure along the embankment centreline 


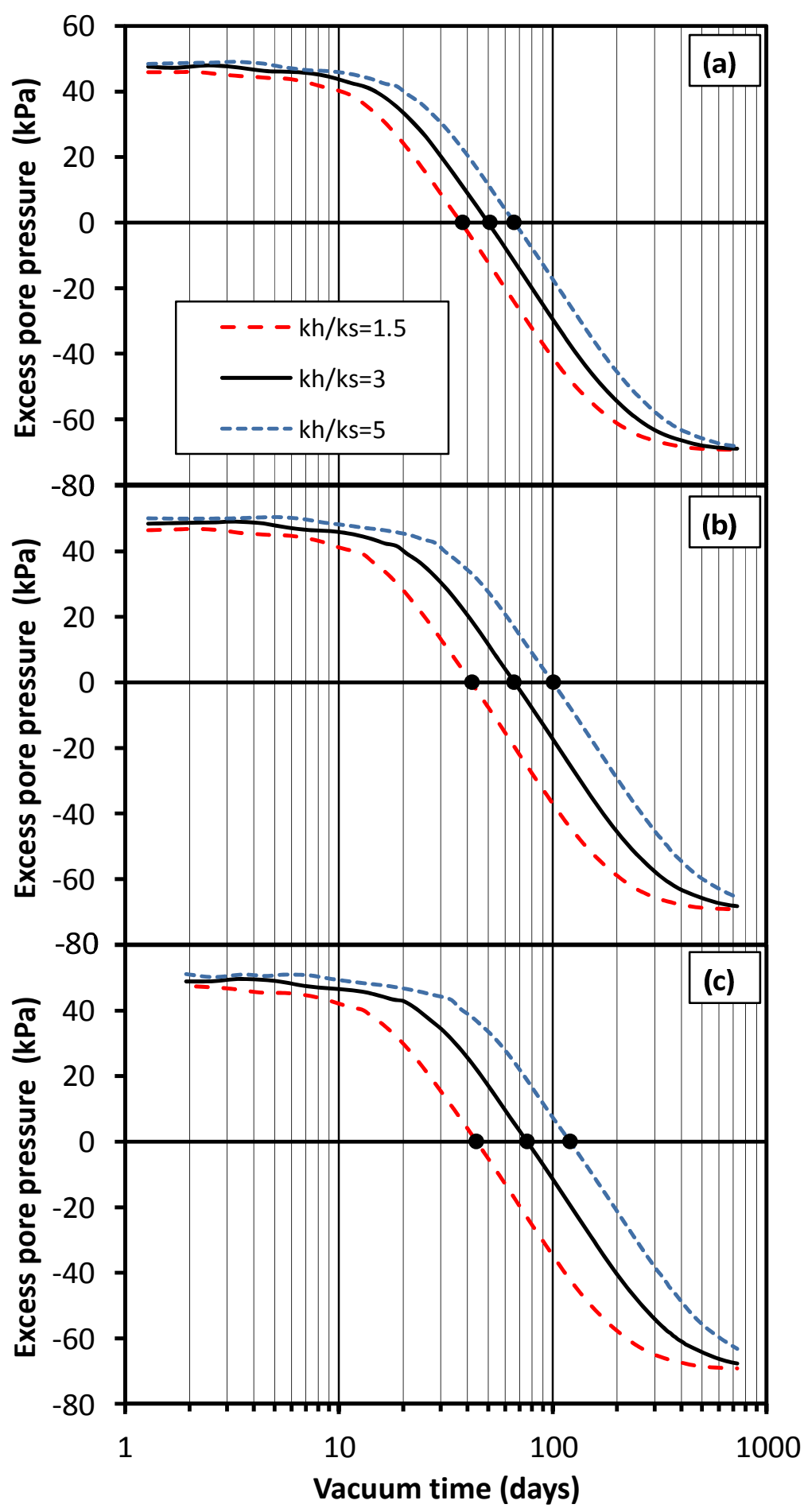

Figure 16: Time history of excess pore pressure at the middle of the soft clay layer for a variety of smear characteristics: (a) $d_{s} / d_{w}=2$, (b) $d_{s} / d_{w}=4$, and (c) $d_{s} / d_{w}=6$ 